\title{
Firm Partisan Political Positioning, Affective Polarization, and Risk Communication: Examining Firms' Voluntary Disclosures on COVID-19
}

\author{
Richard A. Benton ${ }^{1}$ \\ School of Labor and Employment Relations \\ University of Illinois, Urbana-Champaign \\ rabenton@illinois.edu \\ J. Adam Cobb \\ McCombs School of Business \\ University of Texas at Austin \\ adam.cobb@mccombs.utexas.edu \\ Timothy Werner \\ McCombs School of Business \\ University of Texas at Austin \\ timothy.werner@mccombs.utexas.edu
}

November 8, 2020

\begin{abstract}
COVID-19 is among the most salient issues in the world presently, and for many current executives, it is likely to be among the greatest challenges they will face. Upon entering the U.S. context, the disease was immediately subject to the process of affective polarization, with clear partisan splits forming around perceptions of its risks that did not relate to science. We explore whether firms' preexisting political positioning affected how they voluntarily disclosed to their investors on a novel, affectively polarized issue by examining whether firms' disclosure of COVID-19 risks covaries with their partisan political giving. Analyzing conference call and campaign contribution data for the S\&P 500, we find a positive association between a firm's contributions to Democrats and its disclosure of COVID-19 risks.
\end{abstract}

Keywords: COVID-19; managerial risk; affective polarization; corporate political activity; voluntary disclosure

Running Head: Firm Partisan Political Positioning and COVID-19 Risk Communication

\footnotetext{
${ }^{1}$ All authors contributed equally; names are listed alphabetically. Corresponding Author: Richard A. Benton. The authors thank Abhinav Gupta, Robert Prentice, Brian Roberts, Hollis A. Skaife, and Andrew Weaver for their advice and feedback.
} 


\section{Firm Partisan Political Positioning, Affective Polarization, and Risk Communication: Examining Firms' Voluntary Disclosures on COVID-19}

In early November 2019, scientists first identified a novel coronavirus in the Wuhan province of

China. The disease that the virus inflicts, the Novel Coronavirus Disease-2019 or COVID-19, spread rapidly, with the first case in the United States reported on January 21, 2020. By that month's end, the World Health Organization (WHO) declared it a public health emergency, and on March 11, the WHO upgraded the disease to pandemic status. Since that time, much of the world, including the U.S., has undergone a radical social transition as travel restrictions, quarantines, hazard controls, and various social distancing orders became the new normal. Not surprisingly, COVID-19 and the efforts to minimize its impact have had a dramatic impact on business, imposing a set of unique challenges for many corporate executives. Among these challenges, executives must assess the risks that the virus and associated policy responses pose to their firms and decide whether and how to voluntarily disclose those risks to key stakeholders (cf. Hardy \& Maguire, 2020).

Somewhat unique to the U.S., however, is that from the onset, political discourse around the disease took on a particularly politicized nature, whereby conservatives/Republicans view the disease differently than do liberals/Democrats. Nationwide surveys (Agiesta, 2020) and other studies (Barrios \& Hochberg, 2020; van Holm et al., 2020) consistently show that Democrats perceive the risks of COVID-19 as more serious than do Republicans. In fact, many Republican political leaders and many members of the conservative news media continued to downplay the risks of the disease well into March 2020, even as evidence mounted that the disease would have a significant impact on the economy (Green et al., 2020). Political debates about COVID-19 have seemingly been colored heavily by what political scientists refer to as affective 
polarization: the dislike and distrust of members of the other political party as a function of social identity, not policy differences or ideology (Iyengar et al., 2019).

In this paper, we explore whether and how affective polarization impacts the decisionmaking of America's corporate executives. To do so, we examine the association between firms' partisan political positioning (i.e., where they lay on a continuum between Republican and Democrat), as reflected in their corporate political action committee (PAC) donations, and their voluntary disclosures of COVID-19-related risks on quarterly earnings calls. Prior research reveals that executives' political ideologies affect the willingness of firms to adopt risky financing (Hutton et al., 2014) and tax (Christensen et al., 2015) strategies, such that firms led by conservative CEOs exhibit less willingness to engage in risky strategies. This research has led to important discoveries about how correlations between political-psychological tendencies and human behaviors (e.g., conservatives tend to be more risk averse) impact corporate strategies.

In this study, we aim to complement and extend prior work by showing that when an issue becomes affectively polarized, executive responses to it are likely to split on party lines irrespective of those baseline tendencies. Specifically, in the case of COVID-19, conservative elites and those in the broader population have downplayed the risks of the disease whereas liberals have done the opposite. We theorize that due to the affective polarization of COVID-19, executives of Republican-leaning firms will be less willing to voluntarily discuss risks related to the disease in their quarterly earnings calls. This despite the fact that, at baseline, such firms would be assumed to be the most risk averse. In so doing, we consider how a firm's public, partisan political behavior positions it in the broader, increasingly polarized U.S. political system and the consequences its political position has on executive decision-making and risk communications. 
Earnings calls represent an economically important empirical context in which to measure voluntary disclosures of risk, as studies reveal that financial markets react to the information voluntarily shared in these calls above and beyond what is mandated as part of a firm's financial statements (Frankel, Johnson, \& Skinner, 1999; Bushee, Matsumoto, \& Miller, 2003; Chen, Demers, \& Lev, 2018). By voluntarily disclosing its risks, a firm reduces information asymmetry between managers and shareholders, which increases analysts' forecast accuracy and impacts trading behavior (Guo et al., 2020). In so doing, voluntary risk disclosure improves shareholders' trust in the firm's management, which can reduce the firm's cost of capital (Healy \& Palepu, 2001), and reduce the costs incurred from shareholder lawsuits (Skinner, 1997). Timely and accurate voluntary risk disclosure may also improve executives' credibility with analysts and limit their personal liability from adverse events (Skinner, 1994). As such, there is value in understanding the factors that motivate the extent to which executives communicate to the investment community the potential effects of systematic risks, like COVID19. Whether and how such communications are impacted by affective polarization and political positioning is therefore an important, and to our knowledge, a heretofore unstudied phenomenon.

The COVID-19 pandemic provides an excellent test case to study whether affective polarization has spilled-over into the realm of voluntary risk disclosures, and executive decisionmaking more generally, for at least three reasons. First, existing work finds strong ties between conservatism and threat perceptions (e.g., Jost et al., 2003), including the threat of disease (e.g., Beall et al., 2016), as well as a preference for risk-averse corporate strategies (Hutton et al., 2014). Yet, as it pertains to COVID-19, those who identify themselves as conservatives are more likely to see COVID-19 as less threatening than are liberals. As noted above, absent affective polarization of the disease, we would expect Republican-leaning firms to be leerier of the 
business risks associated with COVID-19, and thus more likely to voluntarily disclose those risks to the broader investment community. Because of the politicization of the issue, however, we expect the opposite; providing us a strong test of our proposed theory.

Second, in the early months of the disease's spread, there was uncertainty about the virus, how severe it was, and how best to handle it. Furthermore, in these early months (pre-March 25, 2020), neither securities regulators nor standard setters provided guidance or rules for how firms should communicate with their stakeholders on the issue. Yet, despite this lack of guidance, the potential impacts of the disease were significant enough for most large U.S. firms for their leaders to consider how the disease might impact future performance and whether and how to voluntarily disclose its potential risks to financial analysts and major investors. Third, COVD-19 is a de novo, exogenous issue, which allows for a relatively clean test of whether a firm's preexisting partisan political positioning affects its stated views on a novel and affectively polarized issue. Thus, COVID-19 represents an appealing empirical test case to study the impacts of affective polarization on executive decision-making and firms' voluntary risk disclosures.

The results of both ordinary least squares and matched sample analyses of this relationship in S\&P 500 firms reveal that the more Democratic (Republican) a firm's partisan political positioning is, the greater (lesser) the amount of discussion related to COVID-19 risk by that firm's representatives on its earnings call held during the first quarter of 2020 (January 2 to March 31). Of note, this pattern of results runs counter to those from prior research that, although focused on the level of individual executives, finds that conservative-led firms exhibit greater caution and risk aversion. We also present analyses of the opening statements of earnings calls, the results of which were consistent with those taken from the full earnings calls. Additionally, we analyzed earnings calls in the second quarter of 2020 (April 1 to June 30); the results of 
which were not significant. In further tests, we find that our effects begin diminishing in late March, which roughly corresponds to the point in time in which the Securities and Exchange Commission (SEC) called upon executives to discuss COVID-19 risks in their earnings calls, as well as broader interventions by local, state, and federal governments to minimize the disease's spread and deal with the economic fallout from it. This pattern represents a potential boundary condition of our theory. Specifically, as ambiguity about an issue's risks declines and when executive discretion to discuss it is curtailed, the impact of affective polarization on voluntary risk disclosure may be muted. In sum, given evidence that Republicans more broadly have minimized the disease and its potential impact, our findings provide evidence that affective polarization and a firm's own partisan positioning help to shape its communications of COVID-

19 risks. Moreover, by showing that risk discussions in earnings calls are determined, in part, by an issue's politics and a firm's partisan positioning, this study presents novel evidence that the quality of voluntary financial disclosures can be colored by a firms' political commitments.

\section{THEORY AND HYPOTHESIS}

A key premise undergirding much of contemporary organizational scholarship is the idea that a firm's environment can change, often in unpredictable ways (e.g., Child, 1972; Thompson, 1967). Significant disruptions to a firm's environment, such as natural disasters (Ballesteros \& Gatignon, 2019), financial crises (Flammer \& Ioannou, 2020), political upheavals (Cobb et al., 2017) or, indeed, pandemics cast doubt on prior expectations of firm performance as they create new, and potentially unforeseen risks to the firm (Audia et al., 2000). Following Christensen et al. (2015), we view business risk as arising when "there is uncertainty about both the positive and negative outcomes associated with... activity" (1920). Because executives are tasked with being stewards of their firms, they have strong incentives to objectively assess the risks faced by 
their firms (Davis, Schoorman, \& Donaldson, 1997). They are also expected to communicate these risks to help facilitate understanding among the firm's key stakeholders about the relevant issues facing the firm in light of the disruption (Fjeld et al., 2007).

Yet, not everything that could potentially be defined as a risk is recognized or disclosed as one (Hardy et al., 2020; Douglas \& Wildavksy, 1982). According to upper echelons theory, a firm's willingness to recognize, disclose, and/or take risks, like other strategic choices, is a product of its executives' construal of reality based upon their psychological makeup and experiences (Hambrick, 2007). Psychological factors, and in particular the cognitive models managers adopt, affect managers' construal of the firms' external environment and thus affect their strategic choices with regard to how to best communicate and manage environmental risk (Eggers \& Kaplan, 2013; Helfat \& Peteraf, 2015).

To this end, a long line of psychological research shows that conservatives tend to be more risk-avoidant than are their more liberal counterparts (see, Jost et al., 2003). Researchers have also found that the political ideologies of executives affect their willingness to have their firms engage in risky strategies. For example, Hutton and colleagues (2014) find that Republican executives tend to prefer less risky corporate policies: their firms have lower levels of debt, lower capital and research and development expenditures, and make less risky investments. When facing exogenous, uncertainty-increasing events (e.g., 9/11 attacks, Lehman Brothers bankruptcy), Republican executives enacted even more conservative policies. Research also finds that when firms are led by Republican executives, they are less willing to engage in tax avoidance activities - also a risky strategy (Christensen et al., 2015). These studies provide evidence that the ideology of executives plays a role in determining firms' risk appetites. 
Importantly, however, both firm- and environmental-level factors may constrain executives' ability to rely on their construal of the environment in making risk-related strategic decisions. Principally, the performance, diversification, and size of the firm and the dynamism, complexity, and munificence of the firm's environment, may all influence executives' understanding of and reaction to novel environmental conditions (see, Hoskisson et al., 2017). In this paper, we extend this prior literature in two ways. First, we introduce a new construct to the literature that can also serve as a firm-level constraint on risk-related strategic decisions: a firm's partisan political positioning. A firm's partisan political positioning reflects a firm's "conscious choice" (Baron, 2013: 38) to align itself to a greater or lesser degree with a specific political party in the social, political, and social spaces in which it operates. A firm's public partisan political positioning, therefore, is an actively chosen, collective, and strategic firm-level outcome arrived at by the managers responsible for the firm's corporate political activity and nonmarket strategy more broadly. Further, in the U.S. context, it is an outcome disclosed to the public under the firm's name. Consequently, stakeholders, including politicians and social activists, identify it as the positioning of the firm as a whole (McDonnell \& Werner, 2016).

We view a firm's partisan political positioning as a distinct concept from its organizational political ideology, which Gupta, Briscoe, and Hambrick (2017) define as, "prevailing beliefs among organizational members about how the social world operates, including convictions about what outcomes are desirable and how they should be achieved" (4). A firm's organizational political ideology has deep roots in individuals' psychological make-up and is operationalized based upon aggregating individual behavior. Although the upper echelon directs the firm's observable corporate political activity (Chin et al., 2013) and thereby establishes the firm's partisan political positioning, we argue that because corporate PACs appear 
to follow a pattern of long-term investing in politicians (Snyder, 1992), there is substantial path dependence in a firm's partisan political positioning that helps to anchor that echelon's future acknowledgement of the riskiness of the firm's external environment.

Second and relatedly, we argue that in novel strategic contexts, and absent disclosure regulation or guidance, a firm's voluntary disclosure of risk will be shaped by the relationship between its partisan political positioning and the partisan political nature of the issue generating risk - specifically, whether or not the issue is subject to affective polarization. Many issues related to managerial risk taking and risk disclosure lack a partisan valence, suggesting that a firm's partisan political positioning may not affect executives' understanding of and decisionmaking on such issues. For those that do have a partisan valence, however, the upper echelon of the firm will have a harder time deviating from the partisan political positioning it had previously adopted. That is, if managers publicly align their firm with one party to a greater degree at time $t$, they may, at time $t+\mathrm{n}$ find themselves collectively adopting their preferred party's view of an issue as their firm's view of it. This, in turn, should influence the extent to which the firm voluntarily discloses business risks arising from affectively polarized events. Hence, it may be the case that on an issue that is affectively polarized a firm's partisan political positioning becomes a "core rigidity" (see, Leonard-Barton, 1992), which could potentially turn a nonmarket competitive advantage - e.g., alignment with a political party or actor - into a disadvantage. Baron (2013) refers to such a potential outcome as a "peril of nonmarket positioning" (42).

Recent research in political science suggests that affective polarization is becoming an increasingly significant form of partisan polarization in American political, social, and economic life. Public opinion data reveal that mass political behavior and attitudes are increasingly shaped not by ideology but by "negative partisanship," or sheer dislike, of the opposition (Abramowitz 
\& Webster, 2016). Not only are Americans more distrustful across parties, a process of "affective spillover" has occurred in which partisan allegiances affect social and economic behaviors as far ranging as dating and hiring (Iyengar et al., 2019). Consumers, for example, are less willing to purchase gift cards, even at substantial discounts, from companies that have PACs that contribute to their non-preferred party (McConnell et al., 2018).

Given the dramatic and pervasive spillover effects of affective polarization throughout American life, there is strong reason to suspect that it will similarly impact executive decisionmaking, including voluntary discussion of risk. To be clear, we make no claims about what the 'correct' amount of risk communication should be. Rather, we expect that affective polarization and pre-existing partisan political positioning will shape how firms discuss threats. Determining whether this relationship holds is substantively important because affective polarization may lead executives to view achieving alignment between the firm and its co-partisans on an issue as being more important than recognizing the potential business risks of the issue. In our research setting, affective polarization could therefore undermine the quality of voluntary disclosures, making it harder for financial market participants to understand how the risks of an affectively polarized issue are likely to impact a given firm. These arguments motivate our hypothesis:

Hypothesis 1: In novel strategic contexts, the degree to which a firm voluntarily discloses risk related to an affectively polarized issue will be positively correlated with the degree to which its partisan political positioning aligns with the political party that views the issue as a source of systemic risk.

\section{EMPIRICAL CONTEXT: THE AFFECTIVE POLARIZATION OF COVID-19}

As noted in the introduction, the first phase of the COVID-19 pandemic unfolded over a series of months. On January 7, 2020, cases of pneumonia that had been earlier reported from the Wuhan province in China had been identified as a new coronavirus, and the following day, the U.S.

Centers for Disease Control (CDC) issued its first official health advisory about the outbreak. On 
January 20, Chinese officials confirmed that human-to-human transmission of the virus was possible. The following day the first U.S. case was confirmed and the first earnings call by a firm in our sample (United Airlines Holdings, Inc.) that discussed COVID-19-related risk occurred. Around this time, Google search intensity for the coronavirus began to increase in the U.S. (see, Figure 1 for the across-time distribution in conference calls, as well as firm and public attention to coronavirus), likely reflecting increased media attention to the outbreak (Ducharme, 2020).

\section{[ Insert Figure 1 about here ]}

By the end of January, the WHO had declared the outbreak a "public health emergency of international concern," and the U.S. announced travel restrictions on China. Perhaps unsurprisingly, by this time several firms openly discussed the coronavirus and voluntarily disclosed associated risks in their earnings calls; a trend that, as Figure 1 shows, grew in the following weeks. Further global air restrictions were put in place by the U.S. and other large, industrial countries on February 2. Two days later, the Wall Street Journal published an op-ed warning that a pandemic seemed inevitable (Bario \& Gottlieb, 2020), and the U.S. Senate Intelligence Committee began briefings on the virus. Hence, from mid-January to early February, both governments and the media produced increasing amounts of information that suggested that the coronavirus could present a major health and potentially a significant economic challenge.

To be clear, during this early period there was uncertainty about the virus and the potential for it to disrupt economic activity. Yet, by early February efforts to stem the virus' spread in China were underway, leading to significant declines in export activity from the country (Cerdeiro et al., 2020). Although public health authorities across Europe made interventions to minimize its spread, in the U.S., partisanship colored responses during this period. President Donald Trump, many Republican political leaders, and some members of the 
conservative media continued to downplay the virus' risks into March (Green et al., 2020). For example, despite the Dow Jones Industrial Index dropping 1,000 points on February 24 - the first day in which U.S. stock markets reacted strongly to COVID-19 fears - the president stated that the virus was under control and that the stock market was now undervalued (Stevens, 2020).

By early- to mid-March, however, various levels of the U.S. government began making more significant efforts to curb the disease's spread, as well as to cope with its economic fall-out. The Federal Reserve cut interest rates 0.5 points on March 3, and the president signed an emergency spending bill on March 6. The weekend of March 7 and 8 witnessed a significant price war erupting in oil markets, causing prices to plummet. On March 11, the WHO declared COVID-19 a pandemic, and President Trump announced a travel ban on EU countries. He followed up by declaring a national emergency on March 13. That same day, several U.S. states announced school closures, a trend that continued through that weekend. March 16 witnessed the second worst decline in Dow Jones history, and the S\&P index and NASDAQ declined around 12 percent each. Although only days later President Trump declared that the country will "soon be open for business," by month's end, most U.S. states had imposed stay-at-home orders, over three million Americans filed for unemployment (with 6.5 million more to join them the first week of April), the Federal Reserve announced major interventions in the bond market, and the U.S. Congress passed a $\$ 2$ trillion stimulus package.

We do not claim that each political party had reached full consensus about COVID-19 risks in these early months. However, considerable evidence suggests that COVID-19 became an affectively politicized issue during this time and multiple studies examining individual behavior support this claim. For example, data from the Pew Research Center revealed that in mid-March, Democrats were more likely than Republicans to view the coronavirus as a "major threat to 
public health" (Green \& Tyson, 2020). Relying on location data from a large sample of smartphones, several studies find that in areas with more Republican voters, individuals engaged in less social distancing (e.g., Allcott et al., 2020; Barrios \& Hochberg, 2020; van Holm et al., 2020). ${ }^{2}$ Moreover, at the elite level, Green and colleagues (2020) find that in this early period, Democratic members of Congress discussed the risks of the coronavirus more frequently than did Republicans, and research has shown that similar partisan splits occurred in the media's presentation and discussion of the virus (see, e.g. Jamieson \& Albarracín, 2020). This polarization of political elite discussion of COVID-19 peaked in mid-February and continued into March, which the authors suggest may help explain some of the inter-party variance in behavioral findings observed in other studies.

The emergence of COVID-19 provides an ideal setting in which to test our arguments regarding firms' voluntary disclosure of risk for several reasons. First, because prior research shows that conservatives tend to be more risk averse (Jost et al., 2003) and leerier of the threat of disease (Beall et al., 2016), we should expect that the executives of firms with a Republicanleaning political position would be more cognizant of the risks of COVID-19 and more willing to voluntarily disclose those risks to members of the investment community. In a situation where a political party is more naturally identified with an issue (e.g., Democrats and climate change), it would be difficult to assess the unique effects of affective polarization absent some sort of shock to disrupt long-held beliefs on the issue. In the context of COVID-19, by contrast, we can disentangle the effects of affective polarization from those of baseline, and perhaps psychologically rooted, preferences.

\footnotetext{
${ }^{2}$ Barrios and Hochberg (2020) find that risk perceptions of COVID-19 among Republicans increased after March 9, when it was announced that the virus had struck the Conservative Political Action Committee meetings and several Republican politicians began self-quarantining. This pattern suggests that partisans' "perceptions are affected not by changes in fundamental underlying risk, but rather by political-related interpretations of the risk" (1).
} 
Second, while there was uncertainty as to the ultimate impact of the disease, there is little dispute that it posed risk to many firms in the short- to medium-run. Although other issues are likely to be similarly polarized, they may not affect the performance prospects of most firms in a time frame clear enough to garner mention in firms' communications with analysts and investors, making it more challenging to observe executives' risk assessments on such issues. Additionally, during the early months of the crisis, executives had ample discretion about whether and how to discuss COVID-19 risks, as there was no regulatory guidance about doing so. Finally, because COVID-19 was an exogenous event that was affectively polarized in the U.S. from the onset, COVID-19 could not have shaped firms' prior partisan political positioning. Hence, we can more precisely determine how a firm's prior political positioning affected how firms communicated business risks associated with the disease. Many affectively polarized issues, such as climate change and immigration, are long-standing; thus, they may discursively impact a firm's partisan positioning. Our research design rules out some possible alternative explanations, including concerns of reverse causality.

In sum, we argue that it is reasonable to ask whether a firm will be more or less likely to voluntarily disclose COVID-19 as a business risk based upon its partisan political positioning. If affective polarization has spilled over into firms, then in line with our hypothesis 1 , we would predict that more Democratic-aligned firms will recognize and voluntarily disclose perceived COVID-19 risk at higher levels than Republican-aligned firms.

\section{SAMPLE AND DATA}

To examine the effects of firms' partisan political positioning on the willingness to voluntarily disclose a de novo and politicized risk, we examine the behavior of the cumulative membership of the S\&P 500 index between 1990 and 2020. Our initial sample consists of every firm that 
appeared in the S\&P 500 during this period that was still a going concern as of January $2020 .^{3}$ We link data on disclosed COVID-19 risk, measured using computational text analysis of earnings calls transcripts (Hassan et al., n.d.), with an indicator of corporate political partisanship, constructed using firm PAC contributions to political candidates and political party affiliated committees at the federal level. We also include several firm, industry, and state-level controls constructed from Compustat and other sources.

For our main analyses, we focus on earnings calls held during the first quarter (Q1) of 2020 (i.e., between January 2 and March 31). We do so for two main reasons. First, on March 25, the SEC's Division of Corporate Finance released guidance to firms about the organization's "views regarding disclosure and other securities law obligations that companies should consider with respect to the coronavirus disease." ${ }^{\text {A }}$ On April 8, Jim Clayton, the Chairman of the SEC urged firms to be more forthcoming about the impact of COVID-19, what actions they are taking in response, and what future plans might entail in light of it. ${ }^{5}$ Although neither of these actions had the force of law, research that examines firms' reactions to similar issuances of disclosure guidance in the wake of market downturns and periods of volatility shows that this guidance substantially increases the quantity and quality of firms' disclosures (see, Kravet and Muslu [2013] for a discussion or Leuz and Schrand [2009] for a specific empirical application to SEC guidance issued following the fall of Enron in 2001).

Second, research reveals that the effects of affective polarization are minimized when information is available to counteract it. For example, when asked questions about outcomes

\footnotetext{
${ }^{3}$ The 30-year cumulative population of the S\&P 500 includes 1,181 firms, according to Index Constituents data from Compustat Capital IQ. However, many of these firms delisted their securities for various reasons, particularly mergers and acquisitions over the past 30 years. By early 2020 there remained 521 firms in this population that held Q1 2020 earnings calls. We also removed 8 firms due to missing data on key earnings statement variables.

${ }^{4}$ https://www.sec.gov/corpfin/coronavirus-covid-19

5 https://www.sec.gov/news/public-statement/statement-clayton-hinman
} 
such as GDP growth or unemployment, people's estimates are shaded by their political orientation; they believe that economic outcomes are more (less) favorable when their party is in (out of) power (e.g., Bartels, 2002). Yet, these perceptual biases have been found to be less pronounced when the actual state of the economy is less ambiguous (i.e., uniformly good or bad) (Healy \& Maholtra, 2013). Research on how affective polarization shaped responses to COVID19 also reveals that in areas with high caseloads of the disease, variance in the perceptions of COVID-19 risks between conservatives and liberals dissipated (Druckman et al., 2020). As the threat of COVID becomes more palpable, partisan reasoning diminishes.

Because of the largely unprecedented nature of the economic shutdowns and restrictions occurring throughout the U.S., Europe, and Asia by the end of March, whether there would be, at the minimum, short- to medium-run disruptions and/or performance effects of COVID-19 was difficult to debate for most U.S. firms. Along with these interventions, there were a record number of unemployment claims, and several significant stock market declines. It therefore stands to reason that by late March, the ambiguity about the economic effects of COVID-19 had diminished and the threat of it to business leaders became clearer. That is not to say that one could determine with complete accuracy what the effects of COVID-19 would be for each firm. Rather, the claim here is that as ambiguity about the economic effects of COVID lessened, so too did the potential impact of affective polarization on voluntary risk disclosures.

We acknowledge that affective polarization continued to impact the discourse around the virus into quarter 2 (Q2) and continues to do so at the time of this writing. However, these ongoing debates are less about whether and how COVID-19 will affect society and the economy and have more to do with what the appropriate steps to address the crisis should be. Much of the ambiguity about the potential harm of the virus has dissipated and the SEC issued guidance at the 
start of Q2, which informed our decision to focus on earnings call held in Q1. However, as part of a supplemental analysis, we also analyze data from Q2 (i.e., between April 1 and June 30). We expect that our effects will diminish over time but stress that we might not expect such an effect on other affectively polarized issues, absent clear regulatory guidelines and the emergence of a consensus about whether the issue in question would have an impact on the economy.

\section{Dependent variable: Conference call disclosures of COVID-19 risk}

Our dependent variable captures voluntary firm-level disclosures of COVID-19 related risks, as captured in transcripts from earnings calls that occurred during Q1 of 2020. Computational linguistic analyses of earnings calls transcripts have become popular in several disciplines, particularly in accounting, finance, and economics (Loughran \& McDonald 2013; 2016), and increasingly in the field of strategic management (Guo et al., 2017; Pan et al., 2017). Such methods have become well established for measuring firms' strategic orientations, such as timehorizons (Brochet, Loumioti, \& Serafeim, 2015), sentiment and uncertainty (Loughran \& McDonald, 2011; 2013), optimism about future performance (Davis et al., 2015), and various kinds of firm risks (e.g., Hassan et al., 2019).

Conference call data see myriad applications because in the face of unexpected events, financial market participants rely heavily on the quality of information provided to them by firms to determine how the event is likely to impact firms' prospects. When a firm provides new information, previously private information quickly gets reflected in firms' stock prices (Beaver, 1968). In the face of a novel exogenous event, a firm's disclosures help analysts and investors make sense of the potential impacts on it (Hail, Muhn, \& Oesch, 2020), suggesting that such discussions of risk play a vital role in helping financial markets understand how firms are to likely be impacted by novel events. As noted by Wang, Li, and Xiao (2018), risk disclosure 
serves two main functions. First, it increases the supply of public information by interpreting known risk factors and revealing unknown ones (e.g., a new risk). Doing so improves reporting quality and increases transparency (Elmy, Leguyader, \& Linsmeier, 1998). Second, risk disclosure guides market participants' understanding of the possible range of future performance by the focal firm (Kravet \& Muslu, 2013).

Earnings calls represent a valuable platform for managers to communicate with the investment community. An earnings call is a voluntary quarterly teleconference in which firm officials, often the CEO and/or CFO, discuss operational and financial results from the previous quarter, as well as their outlook for future performance. Although anyone can participate, it is common for analysts following the firm and major investors to attend. Executives frequently discuss economic, industry, or political conditions and how these conditions impact current performance as well as their outlook for future performance. There are two key portions of an earnings call. First, is the firm-generated opening statement (presentation), commonly prepared and/or reviewed by senior managers. Afterwards, a "question and answer" (Q\&A) session is held whereby callers can ask questions of executives who then answer them. Unlike firms' written mandatory disclosures, conference calls contain managers' spoken words and spontaneous conversations between managers and call participants, providing a useful setting to observe managers' disclosure behavior directly (Fu et al., 2019). We provide examples of conference call transcripts with varying levels of discussion related to COVID-19-related risks in Appendix 1.

Studies of earnings transcripts have consistently found that the contents and sentiments expressed in these calls provide information to market participants above and beyond what is contained in financial statements. Several studies reveal that conference calls promote a timelier incorporation of information into stock prices (Kimbrough, 2005), as the contents and sentiments 
expressed in the calls impact investor trading (e.g., Matsumoto et al., 2011). Voluntarily providing new information in earnings calls also leads to greater convergence in valuation opinions among investors (Guo et al., 2020). Thus, conference calls are economically important and provide one of the few avenues through which firms can communicate future risks in an interactive manner with market actors who rely on this information to make decisions.

Although a variety of approaches exist, most earnings call text analysis methods involve computationally searching texts for a set of words or word combinations (bigrams) from predefined dictionaries; dictionaries may be general or purpose specific to capture sentiment related words, risk related words, or time-horizon related statements. Recent work expands on these foundational methods by using earnings calls to measure discussions of specific topics. For example, Hassan et al. (2019) propose a measure characterizing firms' disclosures of political risks. Their approach involves using training libraries of political and non-political texts to identity bigrams that are frequently used in political texts. They then search earnings call transcripts and count the number of instances where political bigrams are used in conjunction with synonyms for risk or uncertainty. Using a series of validation tests, they find that their measure effectively captures firms' disclosures of political risk. Building on this work, Hassan and colleagues have developed similar methods for identifying firm risk disclosures concerning more specific topics, such as Brexit or the Fukushima nuclear disaster (Hassan et al., 2020).

Recently, Hassan and colleagues (Hassan et al., n.d.) proposed a measure of firm disclosures of COVID-19-related risk, as reflected in company earnings calls. Mirroring the above approach, the measure involves counting the number of times the disease is mentioned in the earnings call and measuring the frequency with which these mentions coincide with synonyms for risk or uncertainty. Specifically, the researchers identify common synonyms for 
the disease using online resources and newspaper articles covering COVID-19, combined with hand checks to verify that these disease terms are commonly used in the calls. Using this word list, they construct a measure of disclosed COVID-19 exposure, which is the count of the number of times COVID-19 synonyms are used in the transcript divided by the total number of words in the transcript. This measure captures the proportion of the text that addresses COVID-19. Next, the researchers construct a measure of disclosed COVID-19 related risk by conditioning the search for disease mentions on their proximity to synonyms for risk or uncertainty. The COVID19 risk disclosure measure is the frequency with which the disease is mentioned in conjunction (within 10 words) with a synonym for risk or uncertainty, normalized by transcript length. This measure captures the proportion of the discussion that directly addresses risks related to COVID19. Hassan and colleagues have validated this measure of disclosed COVID-19 risk in several ways, including a manual validation test that reveals that transcripts typically mention COVID19 risks in conjunction with firm-specific concerns regarding a collapse in demand, supply chain disruptions, potential facility closures, and employee welfare.

We use firm COVID-19 risk disclosure exhibited in earnings call transcripts, as constructed by Hassan et al., as our dependent variable. The authors rely on data from the entire transcript to construct their measure of COVID-19 risks, which they make publicly available, as prior research finds that the presentation and Q\&A sections contains distinct information (Matsumoto et al., 2011). We took the additional step of collecting transcripts ourselves to test measures of COVID-19 risks that appear only in the opening remarks of the transcripts. Our rationale for doing so was partly motivated by the fact that because these opening statements are carefully crafted and vetted, that they likely represent a more intentional and conservative 
measure of voluntary COVID-19 risk communication. Wang and Xing (2020) also find that investors react more to COVID-19 related discussions in the presentation section.

To create risk measures with just the opening statements, we first collected copies of the earnings calls for each of our sample firms from the Capital IQ Key Developments Database. We then closely replicated the Hassan et al. (2020) measures by following the method described in their prior studies. ${ }^{6}$ Next, we constructed a similar measure using only the presentation section of the transcripts, thus excluding the Q\&A section. From these texts, we created a measure of COVID-19 risk disclosures-opening, which is measured as the frequency with which the disease is mentioned in the opening statement in conjunction (within 10 words) with a synonym for risk or uncertainty, normalized by the length of the presentation section. This measure captures the proportion of only the presentation section that discusses COVID-19 related risks.

\section{Key explanatory variable: Political partisanship index}

Our focal explanatory variable is a firm-level political partisanship index, measured on a continuous scale from fully Republican (0) to fully Democratic (1). We follow established methods in strategy research in measuring firm political partisanship using contributions to political candidates, parties, and party affiliated committees, as disclosed in U.S. Federal Election Commission (FEC) reporting. In particular, we focus on contributions made by the firm's PAC. Prior research has used corporate PAC contributions and/or executives' contributions to measure corporate political ideology but, for our purposes, corporate PAC

\footnotetext{
${ }^{6}$ Computational text analysis typically involves multiple decisions about data cleaning, tokenization, handling of stop words, and differences in underlying texts that can reflect differences across data vendors. As a result, our constructed measure differs slightly from the original Hassan et al. data due to small differences in transcript construction, data cleaning, and the fact that our underlying data comes from a different source. Although we could not perfectly match their measure, our respective measures of COVID-19 risk disclosure are correlated at 0.967; the statistical and substantive results we present below do not differ if we employ Hassan et al.'s measure or our measure based upon this attempt to exactly replicate theirs.
} 
contributions have a few important advantages as a measure of a firm's partisan political positioning. First, in contrast to executives' giving or firms' spending on lobbying or “dark money," creating and giving through a PAC is perhaps the most thoroughly disclosed method of engaging in federal politics a firm can engage in and contributing to specific politicians and parties creates open associations between the firm and these partisans (Bebchuk \& Jackson, 2010). Second, a firm's PAC is what key stakeholders, including policymakers, consider the voice of the firm in politics, and politicians are sensitive to the associations that stem from accepting corporate PAC contributions (McDonnell \& Werner, 2016; Richter \& Werner, 2017).

Third, whereas CEO, board, and general employee political contributions are perhaps appropriate for measuring ideological commitments, they ultimately capture the political preferences of individuals. By contrast, PAC contributions reflect the partisan preferences of several individuals and the firms' goals (Cohen et al., 2019) and thus are a better measure of how a firm is strategically positioning itself in partisan politics. Lastly, because corporate PACs are typically viewed as access-seeking, pragmatic actors (Bonica, 2016), we expect that PAC contributions offer a more conservative test of our expectation that corporate political leanings affect voluntary COVID-19 risk disclosures than an ideology-focused measure would.

Other than employing PAC contributions in place of individual contributions, we follow the method established by Chin, Hambrick, and Treviño (2013) to measuring a firm's partisan political positioning from political contributions. We include contributions made in the ten years prior to the COVID-19 pandemic (since 2010) in order to have a sufficiently long window to capture stable partisan patterns in political contributions. ${ }^{7}$ Using each firm's PAC contributions,

\footnotetext{
${ }^{7}$ In analyses available upon request, following Gupta et al. (2017), we construct this measure using a shorter PAC contribution window of six years or three election cycles; our results are fully robust. We present the results using the ten-year measure, as it provides more variation in partisan control over both chambers of the U.S. Congress.
} 
we calculate four measures that capture distinct elements of political giving: 1) the number of contributions to Democratic Party candidates or committees, divided by the number of contributions given to both parties; 2) the dollar amount given to Democrats divided by the amount given to both parties; 3 ) the number of years over the (10-year time frame) the firm made contributions to Democrats divided by the number of years contributions were made to either party; and 4) the number of distinct Democratic party recipients to which the firm made contributions divided by the number of distinct recipients of both parties. These four indicators all exhibit similar means and variances, so following Chin et al. (2013) we calculate the simple average to generate our firm-level political partisanship index.

We handle non-contributing firms in two ways. First, we follow Chin et al. (2013) in assigning a political partisanship index score of 0.5 (perfectly moderate) to firms that did not contribute to a political candidate or party affiliated committee during the observation widow. In our regression models, we introduce a dummy variable to flag these non-contributors with an imputed political partisanship score. Second, we estimate a model excluding non-contributors from the sample, and the results are consistent.

\section{Control variables}

We include several control variables that could affect the voluntary disclosure of COVID-19 risks and may be correlated with a firm's partisan political positioning. First, our models control for COVID-19 exposure, as measured by Hassan et al. (n.d.), which measures the extent to which COVID-19 was discussed in the earnings call, without giving weight to whether it was discussed as a significant risk factor. We include it to account for cross-firm variation in whether COVID19 was discussed. COVID-19 exposure is the frequency of COVID-19 synonyms in the earnings call transcript divided by the length of the transcript (number of words). In analyses using 
disclosed COVID-19 risks-opening, we calculated and used a measure of COVID-19 exposureopening using text from the opening statements from the transcripts. Relatedly, we also control for peers' COVID-19 risk disclosure, which we measure as the average COVID-19 risk disclosure scores among other firms in the same 3-digit NAICS industry that held their Q1 earnings call prior to the focal firm's earnings call.

Second, we control for several measures that may affect firms' political giving behavior. Our models control for the proportion of corporate PAC contributions made to incumbents. This control captures the role of contributions in gaining access to lawmakers and accounts for the pragmatic dimension of corporate political activity (Bonica, 2016). Because potential policy responses to COVID-19 response could also come from the state level, we include two measures of state policymaking and ideology: a dummy variable indicating whether the firm's headquarters is in a state with a Democratic governor and a scaled variable running -1 (most conservative) to 1 (most liberal) of the mass liberalism of the public in the firm's headquarters state in 2019, as estimated based upon public opinion data and updated by Caughey and Warshaw (2018). The former measure accounts for the likelihood of emergency policy intervention by the governor, and the latter measure accounts for potential community effects on both a firm's political activity and its early response to COVID-19.

Additionally, we control for firms' disclosed political risks, as indicated in the earnings call transcripts. As defined and validated by Hassan et al. (2019), this measure captures risks associated with political concerns, such as regulation, trade, and government funding. As described above, this measure counts the frequency that political topics are discussed in conjunction with synonyms for risk and uncertainty. In a similar vein, we control for the total annual dollar amount of firm lobbying expenditures, averaged over the prior 10 years. This 
variable is log-transformed to account for right skewness. As an alternative measure, we control for lobbying expenditures for just 2019, which yields consistent results. Data on corporate lobbying come from the Center for Responsive Politics' OpenSecrets lobbying database.

As much of the research in this broader area explores the political ideology of its topmanagement team (e.g., Chin et al., 2013), to rule out the possibility that we are capturing the ideology of the firm's leaders who are frequently featured on earnings calls, we include measures of political ideology for each firms' CEO (CEO political ideology) and CFO (CFO political ideology). To construct these variables, we identified each firm's CEO and CFO in Q1 2020 using Compustat's Execomp database and constructed a political partisanship index for each individual in the same way we did for the firm (i.e., by using their personal campaign contributions as reported to the FEC over the prior 10 years to construct an index).

Not all firms were likely to be adversely affected by COVID-19, suggesting that not all were equally as likely to voluntarily disclose COVID-19 risks in earnings calls. The extent to which these differences affect the relationship between political positioning and disclosed COVID-19 risks, they present potential omitted variables. We measure these factors prior to COVID-19-related disruptions because our dependent variable captures projected risk disclosure, rather than backward looking effects of the disease.

To that end, we first introduce four measures to capture the extent to which firms in our sample were exposed to global market risks. First, we leverage data from Hoberg and Moon (2017; 2019) to create three variables: China exposure, other Asia exposure, and Europe exposure. Analyzing 10-K filings data, Hoberg and Moon count mentions of different countries to capture the extent to which firms are exposed to either input or output risks from each country mentioned. Thus, China exposure represents the number of times "China" is mentioned in these 
financial reports for each firm; Other Asia exposure represents the number of times all Asian countries, except China, are mentioned; and Europe exposure represents the number of times a European country is mentioned in the $10-\mathrm{K}$ statements. The authors validated these measures against data on foreign trade as reported by the U.S. Census Bureau. There are two limitations to our use of these measures: i) 44 firms in our sample had no data on 10-K country mentions; and ii) these data were last updated in 2017 , potentially missing adjustments that firms made in the 2017-2019 period to their foreign exposure, especially to China. We deal with the former through imputation of missing data (discussed further below), and the latter is likely to largely subsumed into industry fixed effects that we include, as the trade war between the U.S. and China has largely affected sectors (e.g., steel, agriculture) as a whole and not individual firms. As an additional effort to control for such exposure using late-2019 data, we also calculated the percentage of foreign revenues from the Compustat segments database. This measure was also not available for all firms in our sample (82 of our 513 sample firms lacked it), but as with the variables above we employ imputation to deal with missingness. Taken together, these variables capture firm-level variance in firms' exposure to foreign markets, which has had a significant effect on stock market reactions in Q1 2020 (Ramelli \& Wagner, 2020).

Research also reveals that in Q1 2020, markets responded more negatively to firms with less cash and with more debt (Ramelli \& Wagner, 2020), the logic being that such firms will have a more difficult time weathering a market downturn. Hence, we control for leverage, which is firms' long-term debt plus debt in current liabilities divided by total assets, and cash/assets, which is cash and short-term investments divided by total assets. Finally, because COVID-19 related disruptions are likely to vary across industry, we include dummies for three-digit NAICS code. Our results are fully robust to employing industry fixed effects at the three-digit SIC code 
level. These measures are taken from Compustat. Furthermore, we control for several indicators of size and performance, including (logged) total assets, return on assets, and market-to-book ratio. These measures are constructed from Compustat. We also control for institutional investor ownership concentration, measured using the Herfindahl-Hirschman Index drawn from Thomson-Reuters data on institutional ownership.

Although analyses reveal that most of the voluntary disclosures of COVID-related risks involved discussion of its effect on demand for firms' products and services and supply chain disruptions, some firms may have also been more apt to voluntarily discuss COVID-19 risks due to their broader stakeholder orientation (Hassan et al., n.d.). Firms with a stronger stakeholder orientation may be more likely to disclose COVID-19 risks, in part, because of the virus' potential impact on workers, the broader community, and society. To help account for this possibility, we include a measure to capture whether firms are more stakeholder minded; we use Sustainalytics' ratings of firms' environment, social, and governance (ESG) factors.

Sustainalytics' ESG rating is a continuous measure comprised of analysts' evaluations along 163 unique indicators, and we employed the latest available composite score data (October 2018). Unfortunately, Sustainalytics does not cover 25 of our sample firms, but as with our foreign exposure variables, as we discuss further below, we address this missingness via imputation.

Finally, we control for the timing of each firm's Q1 earnings call. Although the severity of COVID-19 was initially ambiguous, as time elapsed, the disease's virulence and economic impact became clearer. Therefore, given increased information and salience over time, earnings calls held later in the quarter may be more likely to disclose COVID-19 risks. We thus include a 
continuous control variable that indexes the date of the earnings call, constructed as the number of days after January 1, 2020 that the call was held. ${ }^{8}$

As noted above, there were missing data for several of our control variables, particularly our measures of ESG (Sustainalytics ESG ratings) and foreign trade exposure (China exposure, Other Asia exposure, Europe exposure, and Percentage of foreign revenues). Given our relatively small sample, we aimed to preserve as much of it as we could, and thus, we used multiple imputation techniques to impute missing data for these five variables. ${ }^{9}$

Table 1 presents the descriptive statistics and correlations for our variables.

[ Insert Table 1 about here ]

\section{MODEL AND RESULTS}

We estimate OLS regression models with heteroscedastic robust standard errors. We estimate i) a baseline model that includes only our political partisanship index, ii) a fully specified model with both our political partisanship index and the controls included, iii) the fully specified model run on the subsample that excludes non-contributing firms, and iv) the fully specified model that focuses only on COVID-19 discussion in the presentation section of the earnings call. Table 2 presents these results.

\section{[ Insert Table 2 about here ]}

\footnotetext{
${ }^{8}$ The likelihood that a call discussed of COVID-19 risks may not follow a linear functional form. As alternatives to including this linear time control, we ran analyses using several alternative specifications, including: (a) the squared term of count of days since January 1, 2020, (b) the 7-day cumulative sum of the number of articles published in six major newspaper outlets (Chicago Tribune, Los Angeles Times, New York Times, Wall Street Journal, Washington Post, and USA Today) that mentioned COVID-19 or related synonyms, and (c) the cumulative number of reported COVID-19 cases in the United States. The results are consistent irrespective of specification. We used this linear control as it is easiest to interpret, but analyses with other specifications are available upon request.

${ }^{9}$ We use the multiple imputation with chained equations (mi) in Stata 15. Total ESG and Percent foreign revenue were imputed using OLS regression while China exposure, Other Asia exposure, and Europe exposure were imputed using Poisson regression. We estimated the multiple imputation equations using all other variables in the analysis and produced 10 imputed samples. We also estimated our models using only cases with complete data, and despite reduction in our sample size (from 513 to 378), our results were statistically and substantively significant.
} 
Model 1 estimates the baseline effect of partisan political positioning on firms' voluntarily disclosed COVID-19 risks and shows a significant positive effect for our partisanship index $(\beta=0.052, p<0.05)$, with more Democratic-leaning firms, as indicated by their corporate PAC contributions, being more likely to voluntarily disclose COVID-19-related risks in their earnings calls. Model 2 introduces the fully specified model and indicates that the political partisanship effect is positive and statistically significant $(\beta=0.062, p<0.05)$. In terms of effect size, a one standard deviation increase in Democratic giving on the political partisanship index is associated with a 39 percent increase in voluntarily disclosed COVID-19 related risks. By way of comparison, firms in the airline industry (NAICS 481) disclosed 67 percent more COVID-19 related risks as compared to non-Airline companies during these early months of the pandemic.

Model 3 estimates the fully specified model on the subsample of firms that made political contributions, excluding non-contributors that had been imputed as moderate in the main sample. Model 3 similarly shows a positive and significant political partisanship effect on voluntarily disclosing COVID-19 related risk ( $\beta=0.063, p<0.05$ ). In this model, a one standard deviation increase in Democratic giving, among contributing firms, corresponds to a 37 percent increase in voluntarily disclosed COVID-19 related risks. The consistency of our findings across Models 2 and 3 helps assuage concern that selection into political contributing may affect our results. Finally, Model 4 focuses on voluntarily disclosed COVID-19 related risks in the prepared presentation section of the earnings call, rather than the full transcript. Model 4 shows a positive and significant political partisanship effect on voluntarily disclosing COVID-19 related risks in the presentation section $(\beta=0.106, p<0.05)$. In this model, a one standard deviation increase in Democratic giving corresponds to a 38 percent increase in voluntarily disclosed COVID-19 related risks. In analyses available upon request, we also estimated models using the COVID-19 
risk scores on the Q\&A section alone and found no significant political partisanship effect on COVID-19 related risk. Taken together, these results help assuage concerns that our effects primarily arise due to in analysts' questions in the Q\&A section.

Finally, one possible alternative explanation for our finding is that there are baseline differences in executives' proclivity to talk about business risks more generally based upon their firms' partisan positioning. Imagine, for example, that executives of Democratic-leaning firms were generally more forthcoming in their voluntary communications about risk on earnings calls. To account for this possibility, we conducted a placebo test using data from Hassan et al., (2019) in which we examine whether a firm's partisan political positioning affected its discussion of overall business risk in the Q1 2019. We find no such relationship, suggesting that, consistent with our theorizing, on topics without a partisan valence, a firm's partisan positioning will not impact how its management discusses risk. These results appear in Appendix 2.

\section{Supplemental Analyses}

In addition to our main results, we conducted supplemental analyses to consider i) how the political partisanship effect varies over time and ii) concerns regarding causality.

\section{Time effects}

The main results estimate the effect of political partisanship on COVID-19 voluntary risk disclosure among all Q1 2020 earnings calls for the firms in our sample. However, it is likely that this effect varies over time. In our main results we account for this with a control variable capturing how distant in days from January 1, 2020 the earnings call was. Yet, the time effect is worthy of separate investigation because it could indicate an important scope condition for our theory - partisan political positioning may only induce nonmarket strategic rigidity and thus 
affect risk disclosures when ambiguity is high and/or firms have greater discretion over their disclosures. Broader acceptance of concrete pandemic-related threats and regulatory guidance may vitiate affective polarization's effects by reducing the uncertainty that allows cognitive biases to affect perceptions and behavior and effectively limiting firm discretion, respectively.

To examine differences in the partisan positioning's effect over time, we estimate our main regression model on time-staggered overlapping subsamples using a 50-day window. ${ }^{10}$ We started by estimating our model on a subsample of earnings calls held during the first 50 days of the year (January 1 to February 19). We then estimated the model on progressively later subsamples, advancing the start of our 50 -day sample window by 5 days in each iteration. This strategy allows us to investigate changes in the point estimates and standard errors associated with the partisan political positioning effect as time progresses.

\section{[ Figure 2 about here ]}

Figure 2 presents regression estimates and standard error bars for each of our 11 overlapping temporal subsamples from January 1 through April 9. The figure shows that the estimates were all positive throughout the entire period, indicating a partisan political positioning effect consistent with the main results. However, beginning with the February 9 to March 30 subsample, the political partisanship effect begins to lose statistical significance, as evidenced by the standard error bar including zero. The standard errors expand further in the subsequent time samples. This pattern of results is consistent with the historical progression of the pandemic - by

\footnotetext{
${ }^{10}$ This technique is commonly called temporally recursive regression and is often used for modeling historical processes in time-series data (Griffin \& Isaac, 1992). The technique involves estimating periodized regression models on recursive overlapping historical subsamples to investigate changes in effect sizes and significance levels across historical time (e.g., see, Isaac, Street, \& Knapp, 1994; Abbott, 2001; Isaac \& Christiansen, 2002; Ermakoff, 2019). We experimented with multiple time-window lengths (longer and shorter windows) and multiple time-step iterations (5-day steps, 10-day steps). These analyses were generally consistent with the main results but face tradeoffs in-terms of sample size. Specifically, fewer firms held Q1 earnings calls during later time windows (especially after mid-March), making it challenging to estimate fully specified models. Concomitantly, standard errors increase for these smaller subsample sizes that capture times of the year when fewer earnings calls were held.
} 
late March, there was less ambiguity about the short- to mid-term consequences of the pandemic and the associated stay-at-home orders, the president had declared a national emergency, and more importantly, the SEC had issued guidance concerning COVID-19 related risk disclosures. We also investigated whether partisan political positioning had an effect on COVID-19 risk disclosure in earnings calls held during Q2 2020, and as expected, found no statistically significant partisanship effect during this period.

\section{Matched sample analysis}

We also conducted a matched sample analysis designed to account for pre-pandemic differences in political leanings across firms. This strategy involves i) matching firms that exhibit different political contribution patterns but are otherwise similar on other dimensions and ii) using the matched sample to estimate the effects of political partisanship on differences in voluntary COVID-19 risk disclosure. Although most matching techniques for observational data are applicable only for binary treatment effects, the political partisanship index is a continuous measure and thus requires a different strategy. We adopted a technique called Covariate Balancing Propensity Score Estimation (CBPS), which estimates propensity scores that maximize both the treatment assignment prediction and covariate balance. This strategy avoids the process of iterating between model fitting and balance checking common in most propensity score matching techniques by implementing modeling fitting and balancing simultaneously. Most importantly for our application, CBPS is appropriate for continuous treatment effects and can estimate treatment weights for continuous variables, and these treatment weights can then be 
used to estimate the causal effect of a continuous treatment (Fong, Hazlett, \& Imai, 2018). This process is similar to inverse probability weighting used for binary treatment effects. ${ }^{11}$

We estimated CBPS weights by matching on three dimensions: i) industry, ii) total ESG rating from Sustainalytics, and iii) an exogenous indicator of Democratic party context which is the share of Democratic party held seats in the U.S. Congress from the firm's headquarters state and on the congressional committees with jurisdiction over the firms industry (pooled from 2010 to 2019). ${ }^{12}$ To construct our matching weights, we estimated CBPS weights using Total ESG and Democratic party context within 2-digit industry groups. This strategy allows us to match firms with similar stakeholder orientations and partisan political environments within industry segments. We adopted this approach because industry, stakeholder orientation, and partisan political context can all have substantial effects on firm's partisan political positioning. We then used the CBPS weights to estimate OLS regression models of the causal effect of partisan political positioning. However, note that we were unable to use multiple imputation for missing data on our ESG and foreign trade exposure variables within the CBPS weighted models (see the multiple imputation discussion above). Therefore, these models rely on the subsample of observations with complete data, reducing our sample size from 513 to 348 .

\section{[ Insert Table 3 about here ]}

Table 3 presents the results from OLS regression models with CBPS weights. Model 1 estimates the baseline effect of partisan political positioning on firms' voluntarily disclosed COVID-19 risks and shows a significant positive effect for our partisanship index $(\beta=0.083, p$

\footnotetext{
${ }^{11}$ We implemented CBPS estimation and weighting using the CBPS package in R, https://CRAN.Rproject.org/package=CBPS.

${ }_{12}$ We gathered data on the partisanship of state Congressional delegations from the websites of the Secretary of U.S. Senate and the Clerk of the U.S. House and data on committee ratios from the Congressional Research Service. To match firms to the Congressional committees with jurisdiction over their industry, we employed the mapping created by Ovtchinnikov and Pantaleoni (2012).
} 
$<0.01)$. Model 2 introduces the fully specified CBPS weighted model and indicates that the political partisanship effect is positive and statistically significant $(\beta=0.114, p<0.001)$. Model 3 estimates the fully specified model on the subsample of firms that made political contributions, excluding non-contributors, reducing the sample size to 235 . The model similarly shows a positive and significant political partisanship effect on voluntarily disclosing COVID-19 related risk $(\beta=0.088, p<0.01)$. Finally, Model 4 focuses on voluntarily disclosed COVID-19 related risks in the prepared presentation section of the earnings call, rather than the full transcript. The model shows a positive and significant political partisanship effect on disclosing COVID-19 related risks in the presentation section $(\beta=0.157, p<0.01)$. These findings of our matched sample analyses are fully consistent with our main results, revealing a positive and significant relationship between partisan positioning and voluntary discussions of COVID-19 risks.

\section{DISCUSSION}

The results of this study pose important considerations for scholars of managerial risk and corporate decision-making more broadly. We show that the more Democratic a firm's management had politically positioned the firm prior to the emergence of COVID-19, the more likely the firm's management was to voluntarily disclose risks due to the disease. We believe that these results provide evidence that affective polarization in American politics has spilled over into corporate America. This insight, that affective polarization may be a type of environmentallevel factor that limits how a firm's management can formulate strategy given also the prior partisan political positioning they have chosen for the firm, represents an important theoretical contribution. Further, our operationalization of a firm's partisan political positioning represents an important empirical contribution in that it affects how a firm interacts with its external 
environment and captures an important dimension of a firm's identity in the public sphere that its organizational (or CEO, board, or employee) ideology does not.

Our study holds important practical implications as well. Notably, a large body of evidence points to the importance of firms' voluntary risk disclosures and communications to the broader investment community. That is, investors and analysts rely on executives to provide them with information about the firms' prospects and risks; a fact that is especially important when the firm is confronted with a novel risk (Hail et al., 2020). To our knowledge, ours is the first study to reveal that how executives communicate business risks can be colored by political partisanship. In so doing, our study has key implications for investors and analysts, who must consider that a firm's political positioning may bias executives in ways that lead them to play up or play down certain risks. If such bias is not considered, market actors may form inaccurate judgments of firms' future prospects. Such information may also inform the types of questions market participants ask on such calls in an effort to obtain more accurate information.

In terms of limitations, the mechanism behind our finding needs further unpacking. We argue that recognizing that they are facing an issue characterized by affective polarization, a firm's upper echelon makes decisions about whether and how to discuss COVID-19 risks in a manner that is consistent with the firm's prior partisan political position. Importantly, however, voluntary risk disclosure involves two distinct steps: recognizing the risk and freely disclosing it. We can only observe the latter, however. Ideally, we could observe the conversations that precede the earnings calls to determine whether the executives consider the constraints associated with their partisan political positioning and the politics of the disease in determining whether and how they voluntarily reveal COVID-19 risks. Such information, however, is not widely available. We can also imagine other possible pathways, such as executives relying on 
private information from politicians to whom their firms' PACs contribute money to guide their discussions of COVID-19 risks. Future work relying on other methodologies, such as interviews and case studies may be able to adjudicate between these possible mechanisms.

Our time effects analyses also point to potential boundary conditions in our theory. We see evidence in studies of mass public behavior that individuals in more conservative areas abide more closely to social distancing recommendations when COVID-19 outbreaks increase in their area (Druckman et al. 2020), suggesting that information/uncertainty reduction may minimize the impact of affective polarization on behavior (Healy \& Maholtra, 2013). In our study, however, we cannot know for certain what the differential impacts on voluntary risk disclosure that the SEC's guidance about discussing COVID-19 risks had versus the broader awareness that COVID-19 was significantly and adversely impacting the U.S. (and global) economy. Again, future work relying on other methodologies may be able to adjudicate between these two mitigating factors. More generally, future work should further explore both discretion and uncertainty reduction as boundary conditions to affective polarization on executive decisionmaking. Moreover, given the unique contours of campaign finance in the U.S. and the fact that affective polarization, although present in other polities, is stronger in the U.S. (Boxell, Gentzkow, \& Shapiro, 2020), it is important to study the impact of affective polarization on firms' voluntary risk disclosures, and strategic actions more broadly, on other affectively polarized issues and in other countries.

\section{CONCLUSION}

COVID-19 is among the most salient issues faced by all of society at present, and for the current crop of top executives of firms large and small, it will likely be among the greatest and gravest challenges they will face in their careers. Upon entering the U.S., the disease was almost 
immediately subject to the process of affective polarization, with clear partisan splits forming around perceptions of the risk that it posed that had little to do with ideology or science. This created a unique managerial challenge, and we provide evidence here that indicates, in light of the disease being affectively polarized, firms' preexisting partisan political positioning colored their discussions of it as a business risk.

Exploring the degree to which firms voluntarily acknowledge the risks unleashed by COVID-19 is of critical societal importance given the economic and political challenges the world will face in the next several years due to the disease. Further, such grand challenges are only likely only to increase in frequency and severity (Haass, 2020). We believe that the findings here can help inform how firms will perceive of such present and coming risks, including the inevitable adjustments that will occur because of unmitigated climate change, another critical issue for business and society that has already undergone the process of affective polarization. 


\section{REFERENCES}

Abramowitz, A. I., \& Webster, S. (2016). The rise of negative partisanship and the nationalization of U.S. elections in the 21st century. Electoral Studies, 41(1), 12-22.

Agiesta, J. (2020, 12 May). CNN poll: Negative ratings for government handling of coronavirus persist. CNN.com Retrieved from https://www.cnn.com/2020/05/12/politics/cnn-poll-federalgovernment-handling-of-coronavirus/index.html.

Allcott, H., Boxell, L., Conway, J., Gentzkow, M., Thaler, M., \& Yang, D. Y. (2020). Polarization and public health: Partisan differences in social distancing during the Coronavirus pandemic. National Bureau of Economic Research. Working Paper No. 26946.

Audia, P. G., Locke, E. A., \& Smith, K. G. (2000). The paradox of success: An archival and laboratory study of strategic persistence following radical environmental change. Academy of Management Journal, 43(5), 837-853.

Ballesteros, L., \& Gatignon, A. (2019). The relative value of firm and nonprofit experience: Tackling large-scale social issues across institutional contexts. Strategic Management Journal, 40(4), 631-657.

Baron, D. P. (2013). Business and its environment. Boston: Pearson

Barrios, J. M., \& Hochberg, Y. (2020). Risk perception through the lens of politics in the time of the COVID-19 pandemic. National Bureau of Economic Research. Working Paper No. 27008.

Bartels, L. M. (2002). Beyond the running tally: Partisan bias in political perceptions. Political Behavior, 24. 117-150.

Beall, A. T., Hofer, M. K., \& Schaller, M. (2016). Did the ebola outbreak influence the 2014 U.S. federal elections (and if so, how)? Psychological Science, 27(5), 595-605.

Beaver, W. H. (1968). The information content of annual earnings announcements. Journal of accounting research, 6. 67-92.

Bebchuk, L. A., \& Jackson, Jr., R. J. (2010) Corporate political speech: Who decides? Harvard Law Review, 124, 83-117.

Bolton, A. (2020, 11 May). GOP senators worry Trump, COVID-19 could cost them their majority. The Hill. Retrieved from https://thehill.com/homenews/senate/496898-gop-senatorsworry-trump-covid-19-could-cost-them-their-majority

Bonica, A. (2016). Avenues of influence: On the political expenditures of corporations and their directors and executives. Business and Politics, 18(4), 367-394.

Borio, L. \& Gottlieb S. (2020, February 4). Stop a U.S. coronavirus outbreak before it starts. Wall Street Journal. Retrieved from https://www.wsj.com/articles/stop-a-u-s-coronavirusoutbreak-before-it-starts-11580859525

Boxell, L., Gentzkow, M., \& Shapiro, J. M. (2020). Cross-country trends in affective polarization. National Bureau of Economic Research. Working Paper No. w26669.

Brochet, F., Loumioti, M., \& Serafeim, G. (2015). Speaking of the short-term: Disclosure horizon and managerial myopia. Review of Accounting Studies, 20(3), 1122-1163.

Bullock, J. G., Gerber, A. S., Hill, S. J., \& Huber, G. A. (2015). Partisan bias in factual beliefs about politics. Quarterly Journal of Political Science, 10(4), 519-578.

Bursztyn, L., Rao, A., Roth, C., \& Yanagizawa-Drott, D. (2020). Misinformation during a pandemic. Working paper, University of Chicago.

Bushee, B. J., Matsumoto, D. A., \& Miller, G. S. (2003). Open versus closed conference calls: the determinants and effects of broadening access to disclosure. Journal of Accounting and Economics, 34(1-3), 149-180. 
Caughey, D., \& Warshaw, C. (2018). Policy preferences and policy change: Dynamic responsiveness in the American states, 1936-2014. American Political Science Review, 112(2), 249-266.

Cerdeiro, D. A., Komaromi, A., Liu, Y., \& Saeed, M. (2020). World seaborne trade in real time: A proof of concept for building AIS-based nowcasts from scratch. International Monetary Fund. Working Paper No. 20/57.

Cheema-Fox, A., LaPerla, B. R., Serafeim, G., \& Hui, W. (2020). Corporate resilience and response during COVID-19. Working paper, Harvard Business School.

Chen, J., Demers, E., \& Lev, B. (2018). Oh what a beautiful morning! Diurnal influences on executives and analysts: Evidence from conference calls. Management Science, 64(12):54615959.

Child, J. (1972). Organizational structure, environment and performance: The role of strategic choice. Sociology, 6(1): 1-22.

Chin, M. K., Hambrick, D.C., \& Treviño, L. K. (2013). Political ideologies of CEOs: The influence of executives' values on corporate social responsibility. Administrative Science Quarterly, 58(2), 197-232.

Christensen, D. M., Dhaliwal, D. S., Boivie, S., \& Graffin, S. D. (2015). Top management conservatism and corporate risk strategies: Evidence from managers' personal political orientation and corporate tax avoidance. Strategic Management Journal, 36(12), 1918-1938.

Cobb, J. A., Wry, T., \& Zhao, E. Y. (2017). Funding financial inclusion: Institutional logics and the contextual contingency of funding for microfinance organizations. Academy of Management Journal, 59(6), 2103-2131.

Cohen, A., Hazan, M., Tallarita, R., \& Weiss, D. (2019). The politics of CEOs. Journal of Legal Analysis, 11(1), 1-45.

Davis, A. K., Ge, W., Matsumoto, D., \& Zhang, J. L. (2015). The effect of manager-specific optimism on the tone of earnings conference calls. Review of Accounting Studies, 20(2), 639673.

Davis, J. H., Schoorman, F. D., \& Donaldson, L. (1997). Toward a stewardship theory of management. Academy of Management Review, 22(1), 20-47.

Devers, C. E., Wiseman, R. M., Holmes, Jr., R. M. (2007). The effects of endowment and loss aversion in managerial stock option valuation. Academy of Management Journal, 50(1), 191208.

Douglas, M., \& Wildavsky, A. B. (1982). Risk and culture: An essay on the selection of technical and environmental dangers. Berkeley, CA: University of California Press.

Ducharme, J. (2020, February 7). News coverage of coronavirus in 2020 is very different than it was for ebola in 2018. Time. Retrieved from https://time.com/5779872/coronavirus-ebolanews-coverage/

Druckman, J. N., Klar, S., Krupnikov, Y., Levendusky, M., \& Ryan, J. B. (2020). How affective polarization shapes Americans' political beliefs: A study of response to the COVID-19 pandemic. Journal of Experimental Political Science, 1-20.

Eggers, J. P., \& Kaplan, S. (2013). Cognition and capabilities: A multi-level perspective. Academy of Management Annals, 7, 295-340.

Elmy, F. J., LeGuyader, L. P., \& Linsmeier, T. J. (1998). A review of initial filings under the SEC's new market risk disclosure rules. Journal of Corporate Accounting \& Finance, 9(4), 3345. 
Fjeld, R. A., Eisenberg, N. A., \& Compton, K. L. (2007). Quantitative environmental risk analysis for human health. Hoboken, NJ: John Wiley \& Sons.

Flammer, C., \& Ioanou, I., (2020). Strategic Management During the Financial Crisis: How Firms Adjust Their Strategic Investments in Response to Credit Market Disruptions. Working Paper, Boston University.

Fong, C., Hazlett, C., \& Imai, K. (2018). Covariate balancing propensity score for a continuous treatment: Application to the efficacy of political advertisements. The Annals of Applied Statistics, 12(1), 156-177.

Frankel, R., Johnson, M., \& Skinner, D. J. (1999). An Empirical Examination of Conference Calls as a Voluntary Disclosure Medium. Journal of Accounting Research, 37(1), 133-150.

$\mathrm{Fu}, \mathrm{X}$., Wu, X., \& Zhang, Z. (2019). The Information Role of Earnings Conference Call Tone: Evidence from Stock Price Crash Risk. Journal of Business Ethics, 1-18.

Green, J., Edgeron, J., Naftel, D., Shoub, K., \& Cranmer, S. J. (2020). Elusive consensus: Polarization in elite communication on the COVID-19 pandemic. Science Advances, 6(28), eabc2717.

Green, T. V., \& Tyson, A. (2020, April 2). 5 facts about partisan reactions to COVID-19 in the U.S. Pew Research Center. Retrieved from https://www.pewresearch.org/facttank/2020/04/02/5-facts-about-partisan-reactions-to-covid-19-in-the-u-s/

Griffin L. J. \& Isaac, L. W. (1992) Recursive regression and the historical use of "time" in timeseries analysis of historical process. Historical Methods: A Journal of Quantitative and Interdisciplinary History, 25(4), 166-179.

Guo, W., Sengul, M., Yu, T., (2020). The Impact of Executive Verbal Communication on the Convergence of Investors' Opinions. Academy of Management Journal, In Press.

Guo, W., Yu, T., \& Gimeno, J. (2017). Language and competition: Communication vagueness, interpretation difficulties, and market entry. Academy of Management Journal, 60(6), 20732098.

Gupta, A., Briscoe, F., \& Hambrick, D. C. (2017). Red, blue, and purple firms: Organizational political ideology and corporate social responsibility. Strategic Management Journal, 38(5), 1018-1040.

Hail, L., Muhn, M., \& Oesch, D. (2020). Do Risk Disclosures Matter When It Counts? Evidence from the Swiss Franc Shock. Journal of Accounting Research, In Press.

Hambrick, D. C. (2007). Upper echelons theory: An update. Academy of Management Review, 32(2), 334-343.

Hardy, C. \& Maguire, S. (2020). Organizations, risk translation, and the ecology of risks: The discursive construction of a novel risk. Academy of Management Journal, 63(2), 685-716.

Hardy, C. Maguire, S., Power, M., \& Tsoukas, H. (2020). Organizing risk: organization and management theory for the risk society. Academy of Management Annals, 14(2), 1032-1066.

Hassan, T. A., Hollander, S., van Lent, L., \& Tahoun, A. (2019). Firm-level political risk:

Measurement and effects. Quarterly Journal of Economics 134(4), 2135-2202.

Hassan, T. A., Hollander, S., van Lent, L., \& Tahoun, A. (2020). The global impact of Brexit uncertainty. National Bureau of Economic Research. Working Paper No. 26609.

Hassan, T. A., Hollander, S., van Lent, L., \& Tahoun, A. (n.d.) Firm-level exposure to epidemic diseases: COVID-19, SARS, and H1N1.

Haass, R. (2020). The world: A brief introduction. New York: Penguin Press.

Hayward, M. L. A., Hambrick, D. C. (1997). Explaining the premiums paid for large acquisitions. Administrative Science Quarterly, 42(1), 103-127. 
Healy, A. \& Malhotra, N. (2013). Retrospective voting reconsidered. Annual Review of Political Science, 16, 285-306.

Healy, P. \& Palepu, K. (2001). Information asymmetry, corporate disclosure, and the capital markets: A review of the empirical disclosure literature. Journal of Accounting and Economics, 31(1), 405-440.

Helfat, C. E., \& Peteraf, M. A. (2015). Managerial cognitive capabilities and the microfoundations of dynamic capabilities. Strategic Management Journal, 36(6), 831-850.

Hoberg, G., \& Moon, S. K. (2017). Offshore activities and financial vs operational hedging. Journal of Financial Economics, 125(2), 217-244.

Hoberg, G., \& Moon, S. K. (2019). The offshoring return premium. Management Science, 65(6), 2876-2899.

Hoskisson, R. E., Chirico, F., Zyung, J., \& Gambeta, E. (2017). Managerial risk taking: A multitheoretical review and future research agenda. Journal of Management, 43(1), 137-169.

Hutton, I., Jiang, D., \& Kumar, A. (2014). Corporate policies of Republican managers. Journal of Financial and Quantitative Analysis, 49(5-6), 1279-1310.

Iyengar, S., Lelkes, Y., Levendusky, M., Malhotra, N., \& Westwood, S. J. (2019). The origins and consequences of affective polarization in the United States. Annual Review of Political Science, 22, 129-146.

Jamieson, K. H., \& Albarracin, D. (2020). The Relation between media consumption and misinformation at the outset of the SARS-CoV-2 pandemic in the U.S. The Harvard Kennedy School Misinformation Review.

Jost, J., Glaser, J., Kruglanski, A., \& Sulloway, F. 2003. Political conservatism as motivated social cognition. Psychological Bulletin, 129(3), 339-375.

Kimbrough, Michael. (2005). The effect of conference calls on analyst and market underreaction to earnings announcements. The Accounting Review, 80(1), 189-219.

Kravet, T., \& Muslu, V. (2013). Textual risk disclosures and investors' risk perceptions. Review of Accounting Studies, 18(4), 1088-1122.

Leonard-Barton, D. (1992). Core capabilities and core rigidities: a paradox in managing product development. Strategic Management Journal, 13(S2), 111-125.

Leuz, C., \& Schrand, C. (2009). Disclosure and the cost of capital: Evidence from firms' responses to the Enron shock. National Bureau of Economic Research. Working Paper No. 14897.

Loughran, T., \& McDonald, B. (2011). When is a liability not a liability? Textual analysis, dictionaries, and 10-Ks. Journal of Finance, 66(1), 35-65.

Loughran, T., \& McDonald, B. (2013). IPO first-day returns, offer price revisions, volatility, and Form S-1 language. Journal of Financial Economics, 109(2), 307-326.

Loughran, T., \& McDonald, B. (2016). Textual analysis in accounting and finance: A survey. Journal of Accounting Research, 54(4), 1187-1230.

Matsumoto, D., Pronk, M., \& Roelofsen, E. (2011). What makes conference calls useful? The information content of managers' presentations and analysts' discussion sessions. The Accounting Review, 86(4), 1383-1414.

McConnell, C., Malhotra, N., Margalit, Y., \& Levendusky, M. (2018). The economic consequences of partisanship in a polarized era. American Journal of Political Science, 62(1), $5-18$.

McDonnell, M-H., \& Werner, T. (2016). Blacklisted businesses: Social activist challenges and the disruption of corporate political activity. Administrative Science Quarterly, 61(4), 584-620. 
Ovtchinnikov, A. V., \& Pantaleoni, E. (2012). Individual political contributions and firm performance. Journal of Financial Economics, 105(2), 367-392.

Pan, L., McNamara, G., Lee, J. J., Haleblian, J., \& Devers, C. E. (2018). Give it to us straight (most of the time): Top managers' use of concrete language and its effect on investor reactions. Strategic Management Journal, 39(8), 2204-2225.

Ramelli, S., \& Wagner, A. F. (2020). Feverish stock price reactions to COVID-19. The Review of Corporate Finance Studies, 9(3), 622-655.

Richter, B. K., \& Werner, T. (2017). Campaign contributions from corporate executives in lieu of political action committees. Journal of Law, Economics, and Organization, 33(3), 443-474.

Skinner, D. J. (1994). Why Firms Voluntarily Disclosure Bad News. Journal of Accounting Research, 32(1), 38-60.

Skinner, D. J. (1997). Earnings disclosures and stockholder lawsuits. Journal of Accounting and Economics, 23(3), 249-282.

Stevens, P. (2020, February 25). Trump is reportedly furious that the stock market is plunging on coronavirus fears. CNBC. Retrieved from https://www.cnbc.com/2020/02/25/trump-isreportedly-furious-with-the-plunging-stock-market-due-to-coronavirus-fears.html

Snyder, Jr., J. M. (1992). Long-term investing in politicians; Or, give early, give often. Journal of Law \& Economics, 35(1), 15-43.

Thompson, James. D. 1967. Organizations in action, New York: McGraw-Hill.

van Holm, E. J., Monaghan, J., Shahar, D. C., Messina, J. P., \& Surprenant, C. (2020). The impact of political ideology on concern and behavior during COVID-19. Working paper, University of New Orleans.

Wang, X., Li, Y., \& Xiao, M. (2017). Do risk disclosures in annual reports improve analyst forecast accuracy? China Journal of Accounting Studies, 5(4), 527-546.

Wang, V. X., \& Xing, B. (2020). Battling Uncertainty: Corporate Disclosures of COVID-19 in Earnings Conferences Calls and Annual Reports (April 28, 2020). Available at SSRN: http://dx.doi.org/10.2139/3586085. 
Table 1: Descriptive statistics and correlation matrix ${ }^{\mathrm{a}}$

\begin{tabular}{|c|c|c|c|c|c|c|c|c|c|c|c|c|c|c|c|c|c|c|c|c|c|c|c|c|}
\hline & Mean & S.D. & 1. & 2. & 3. & 4. & 5. & 6. & 7. & 8. & 9. & 10. & 11. & 12. & 13. & 14. & 15. & 16. & 17. & 18. & 19. & 20. & 21. & 22. \\
\hline 1. Disclosed Covid-19 Risk & .02 & .07 & & & & & & & & & & & & & & & & & & & & & & \\
\hline 2. Political Partisanship Index & .44 & .11 & .04 & & & & & & & & & & & & & & & & & & & & & \\
\hline 3. Prop. contributed to incumbents & .53 & .42 & -.03 & -.33 & & & & & & & & & & & & & & & & & & & & \\
\hline 4. CEO Partisanship Index & .39 & .27 & -.03 & .36 & -.06 & & & & & & & & & & & & & & & & & & & \\
\hline 5. CFO Partisanship Index & .45 & .24 & .00 & .22 & -.05 & .25 & & & & & & & & & & & & & & & & & & \\
\hline 6. Disclosed Covid-19 Exposure & .26 & .50 & .61 & .09 & -.16 & .09 & .03 & & & & & & & & & & & & & & & & & \\
\hline 7. Disclosed Political Risk & 127.09 & 208.10 & .22 & -.01 & .01 & -.05 & -.02 & .19 & & & & & & & & & & & & & & & & \\
\hline 8. Peers' Disclosed Covid-19 Risk & .01 & .02 & .19 & .06 & -.09 & .16 & .04 & .51 & .07 & & & & & & & & & & & & & & & \\
\hline 9. Lobbying expenditures ${ }^{b}$ & 6.79 & 8.01 & .00 & -.22 & .49 & -.06 & .00 & -.10 & .15 & -.13 & & & & & & & & & & & & & & \\
\hline 10. Total Assets ${ }^{\mathrm{b}}$ & 9.88 & 1.43 & -.09 & -.02 & .36 & -.02 & -.01 & -.15 & .06 & -.11 & .37 & & & & & & & & & & & & & \\
\hline 11. Return on assets & .05 & .09 & .04 & .09 & -.05 & .05 & .03 & .09 & -.02 & -.01 & .04 & -.14 & & & & & & & & & & & & \\
\hline 12. Cash on hand & .09 & .12 & -.01 & .23 & -.09 & .26 & .14 & .08 & -.01 & .09 & -.09 & -.16 & .32 & & & & & & & & & & & \\
\hline 13. Leverage & .34 & .21 & -.01 & -.07 & .07 & -.14 & .01 & -.01 & -.03 & -.01 & -.00 & -.01 & -.03 & -.20 & & & & & & & & & & \\
\hline 14. Market-to-book & 1.39 & 70.58 & .02 & -.03 & .05 & -.02 & -.01 & .02 & .02 & .03 & -.01 & .01 & -.02 & .02 & -.08 & & & & & & & & & \\
\hline 15. Institutional investors (HHI) & .09 & .18 & -.03 & .02 & .06 & .06 & .02 & -.00 & -.03 & .12 & .06 & .09 & .15 & -.10 & .01 & .02 & & & & & & & & \\
\hline 16. HQ state Democratic governor & .62 & .49 & -.01 & .20 & .03 & .19 & .14 & .01 & .05 & .00 & .02 & .05 & .07 & .23 & -.06 & .06 & -.07 & & & & & & & \\
\hline 17. HQ state policy index & .65 & 1.65 & .08 & .34 & -.05 & .26 & .27 & .08 & .03 & .03 & -.01 & .04 & .13 & .38 & -.12 & .07 & -.03 & .55 & & & & & & \\
\hline 18. ESG Rating & 57.92 & 8.51 & .09 & -.01 & .14 & -.03 & .03 & .10 & .09 & .10 & .20 & .33 & .04 & -.03 & .07 & -.09 & -.00 & .09 & .17 & & & & & \\
\hline 19. China-exposure & 5.67 & 10.76 & .17 & .03 & -.05 & .12 & .05 & .24 & -.08 & .21 & -.03 & -.15 & -.01 & .11 & -.01 & .03 & .06 & .04 & .08 & .15 & & & & \\
\hline 20. Other Asia-exposure & 16.88 & 27.77 & .12 & .03 & -.05 & .07 & -.00 & .22 & -.02 & .19 & -.01 & -.03 & .02 & .12 & -.01 & .02 & .02 & .02 & .10 & .21 & .54 & & & \\
\hline 21. Europe-exposure & 23.19 & 33.74 & .13 & -.03 & .03 & .07 & .10 & .13 & .08 & .13 & .02 & -.06 & -.02 & .05 & .01 & .01 & .08 & .03 & .07 & .03 & .39 & .51 & & \\
\hline 22. Percentage foreign revenue & .45 & .41 & 19 & .13 & -.07 & .15 & .08 & .27 & -.02 & .26 & -.06 & -.08 & .05 & .24 & -.05 & -.10 & .05 & .14 & .21 & .16 & .33 & .39 & .34 & \\
\hline 23. Call date (days since Jan 1,2020 ) & 37.19 & 13.14 & .26 & -.04 & -.09 & .01 & -.02 & .44 & .04 & .28 & -.13 & -.08 & -.09 & -.12 & .11 & .05 & -.01 & -.13 & -.14 & -.01 & .00 & .01 & .01 & -.07 \\
\hline
\end{tabular}

$\begin{array}{llll}37.19 & 13.14 & .26 & -.04\end{array}$

${ }^{\mathrm{b}}$ Variable is log-transformed. 
Table 2: OLS regression models predicting disclosed COVID-19-related risks ${ }^{\mathrm{a}}$

\begin{tabular}{|c|c|c|c|c|}
\hline & (1) & (2) & (3) & (4) \\
\hline & Full Text & Full Text & Full Text & Presentation Text \\
\hline \multirow[t]{2}{*}{ Political Partisanship Index } & $.052^{*}$ & $.062^{*}$ & $.063^{*}$ & $.109^{*}$ \\
\hline & $(.021)$ & $(.024)$ & $(.029)$ & $(.052)$ \\
\hline \multirow[t]{2}{*}{ Disclosed Covid-19 Exposure } & $.098^{* * *}$ & $.102^{* * *}$ & $.126^{* * *}$ & $.130^{* *}$ \\
\hline & $(.022)$ & $(.024)$ & $(.033)$ & $(.039)$ \\
\hline \multirow[t]{2}{*}{ Incumbent Contributions } & & .000 & .004 & -.023 \\
\hline & & $(.015)$ & $(.016)$ & $(.029)$ \\
\hline \multirow[t]{2}{*}{ CEO Partisanship Index } & & -.010 & -.014 & -.054 \\
\hline & & $(.013)$ & $(.017)$ & $(.036)$ \\
\hline \multirow[t]{2}{*}{ CFO Partisanship Index } & & -.006 & -.010 & -.005 \\
\hline & & $(.010)$ & $(.012)$ & $(.026)$ \\
\hline \multirow[t]{2}{*}{ Disclosed Political Risk } & & .000 & .000 & .000 \\
\hline & & $(.000)$ & $(.000)$ & $(.000)$ \\
\hline \multirow[t]{2}{*}{ Peers' Disclosed Covid-19 Risk } & & $-.604^{*}$ & $-.830^{*}$ & -.637 \\
\hline & & $(.239)$ & $(.334)$ & $(.506)$ \\
\hline \multirow[t]{2}{*}{ Lobbying expenditures ${ }^{b}$} & & .000 & -.001 & .000 \\
\hline & & $(.000)$ & $(.001)$ & $(.001)$ \\
\hline \multirow[t]{2}{*}{ Total assets ${ }^{b}$} & & -.004 & -.004 & -.007 \\
\hline & & $(.004)$ & $(.005)$ & $(.010)$ \\
\hline \multirow{2}{*}{ Return on assets } & & -.037 & -.058 & -.095 \\
\hline & & $(.031)$ & $(.044)$ & $(.063)$ \\
\hline \multirow{2}{*}{ Cash on hand } & & -.020 & .009 & -.052 \\
\hline & & $(.025)$ & $(.038)$ & $(.057)$ \\
\hline \multirow[t]{2}{*}{ Leverage } & & -.003 & .003 & .019 \\
\hline & & $(.014)$ & $(.020)$ & $(.034)$ \\
\hline \multirow[t]{2}{*}{ Market to Book } & & -.000 & $.000^{* * * *}$ & -.000 \\
\hline & & $(.000)$ & $(.000)$ & $(.000)$ \\
\hline \multirow[t]{2}{*}{ Institutional investors (HHI) } & & .001 & .007 & -.009 \\
\hline & & $(.010)$ & $(.015)$ & $(.013)$ \\
\hline \multirow[t]{2}{*}{ HQ state Democratic governor } & & .002 & .001 & -.014 \\
\hline & & $(.009)$ & $(.010)$ & $(.023)$ \\
\hline \multirow[t]{2}{*}{ HQ state mass liberalism } & & .000 & -.001 & .006 \\
\hline & & $(.003)$ & $(.003)$ & $(.007)$ \\
\hline \multirow[t]{2}{*}{ ESG Rating } & & .000 & .000 & -.000 \\
\hline & & $(.000)$ & $(.000)$ & $(.001)$ \\
\hline \multirow[t]{2}{*}{ China-exposure } & & .000 & .000 & .000 \\
\hline & & $(.000)$ & $(.001)$ & $(.001)$ \\
\hline \multirow[t]{2}{*}{ Other Asia-exposure } & & -.000 & -.000 & -.000 \\
\hline & & $(.000)$ & $(.000)$ & $(.000)$ \\
\hline \multirow[t]{2}{*}{ Europe-exposure } & & .000 & .000 & -.000 \\
\hline & & $(.000)$ & $(.000)$ & $(.000)$ \\
\hline Percentage foreign revenue & & .008 & .018 & .029 \\
\hline & & $(.009)$ & $(.012)$ & $(.020)$ \\
\hline Call date (days since Jan 1,2020 ) & -.000 & .000 & .000 & .001 \\
\hline & $(.000)$ & $(.001)$ & $(.001)$ & $(.001)$ \\
\hline Partisanship index imputed flag & $-.021^{* *}$ & -.023 & & $-.068^{*}$ \\
\hline & $(.007)$ & $(.012)$ & & $(.026)$ \\
\hline Constant & -.002 & .018 & .019 & .110 \\
\hline & $(.019)$ & $(.062)$ & $(.078)$ & $(.159)$ \\
\hline Industry FEs & Yes & Yes & Yes & Yes \\
\hline$N$ & 513 & 513 & 339 & 513 \\
\hline$r^{2}$ & .48 & .50 & .61 & .40 \\
\hline
\end{tabular}

${ }^{a}$ Robust standard errors in parentheses.

${ }^{\mathrm{b}}$ Variable is log-transformed. 
Table 3: CBPS Weighted OLS regression models predicting disclosed COVID-19 related risks ${ }^{\mathrm{a}}$

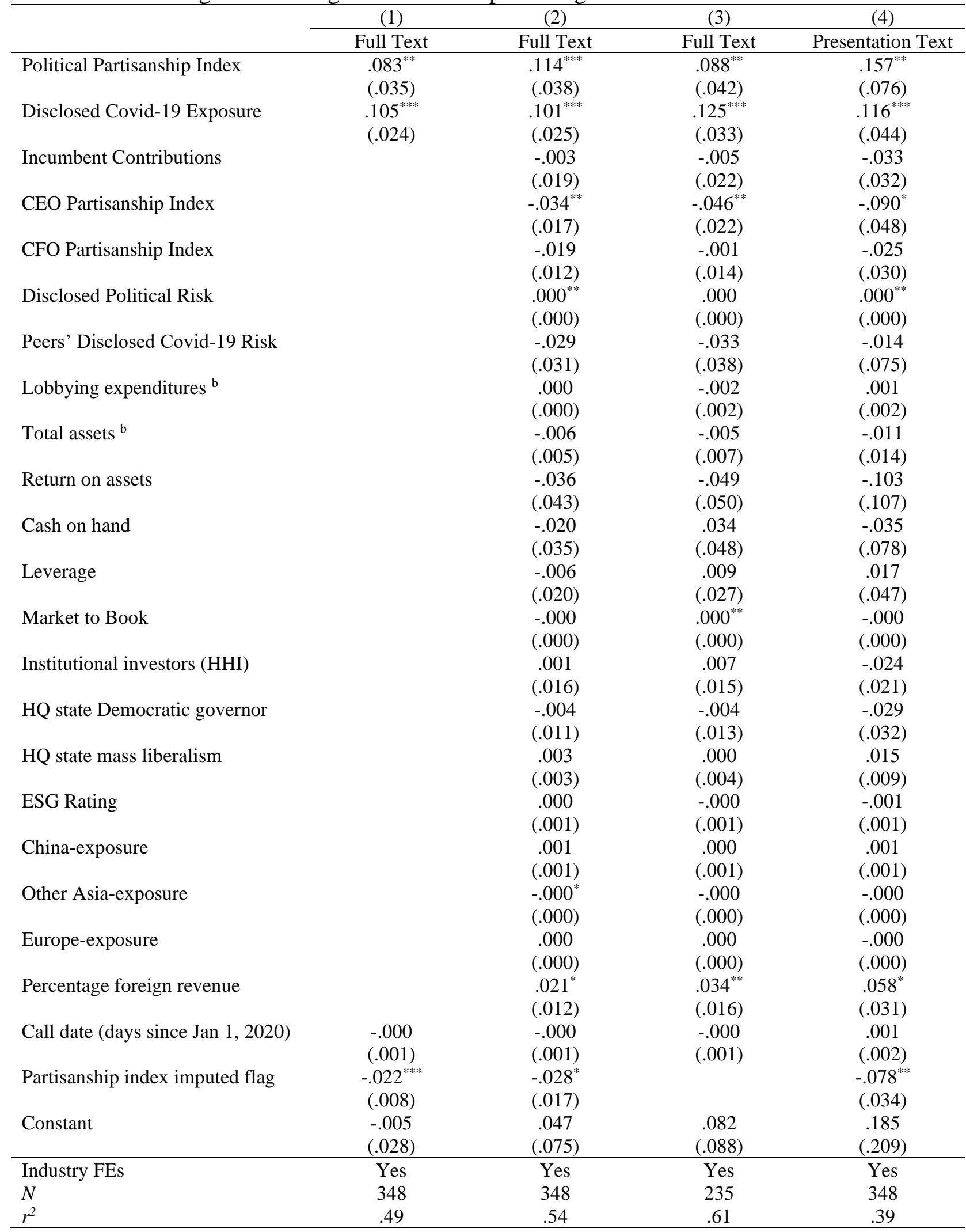

${ }^{a}$ Robust Standard errors in parentheses

${ }^{\mathrm{b}}$ Variable is log-transformed 
Figure 1: Earnings Calls and Google Search Trends

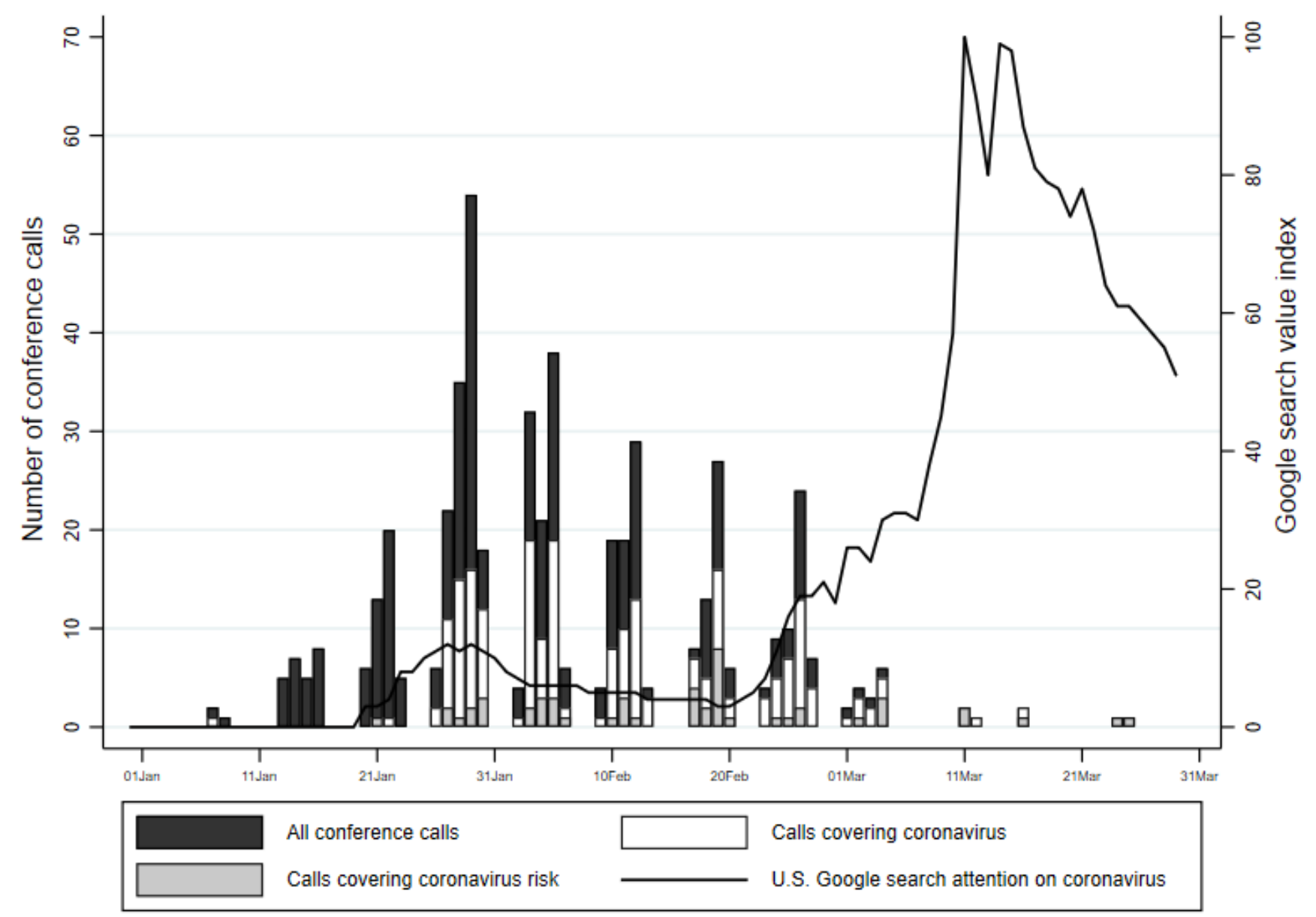


Figure 2: Estimates and Standard Errors from Temporally Recursive OLS Regression Models Overlapping Fifty Day Subsamples from January 1 to April 9

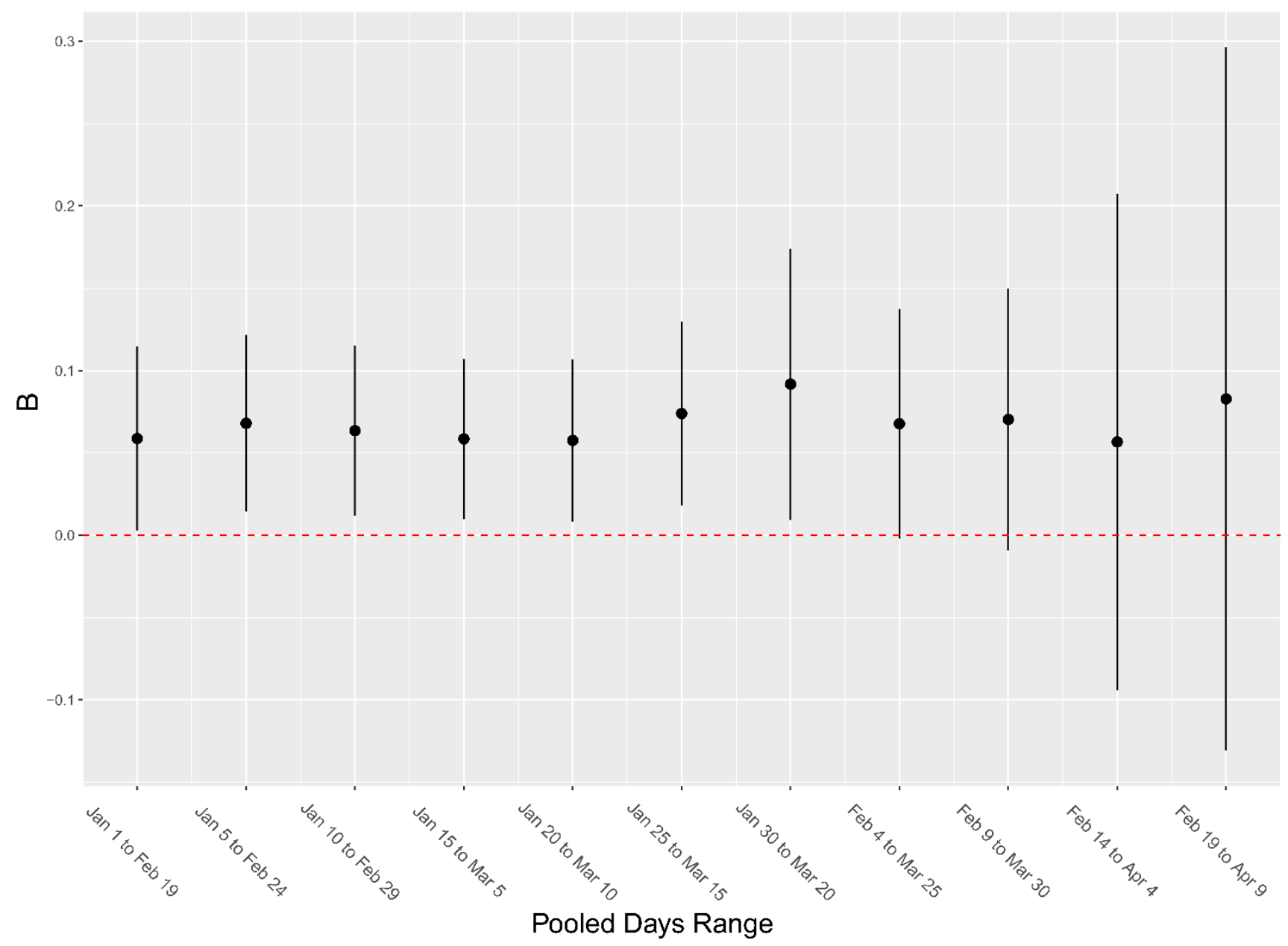

Note: Regression estimates and standard errors from Temporally Recursive regression models using 5-day increment overlapping 50-day subsamples from January 1, 2020 to April 9, 2020. 
Supplementary Appendices for "Firm Partisan Political Positioning and Perceptions of COVID-19-Related Risk"

November 8, 2020 


\section{Supplementary Appendix 1}

This supplementary appendix presents three excerpts from the preambles of conference calls held by members of the S\&P 500 during the first calendar quarter of 2020. They are Devon Energy, Leggett \& Platt, and Delta Airlines. We chose these firms as exemplars because they cross-industry boundaries (energy, diversified manufacturing, and passenger air travel), but all three are from industries that are affected by COVID-19. We present the three in the order of the degree to which the discuss perceptions of the business risks posed by COVID-19. First, Devon Energy does not mention the disease in any manner; second, Leggett \& Platt discusses the disease but largely in terms of its broad potential impacts on the economy and specifically, notes that they are not providing any guidance with regard to COVID-19-related risks; and third, Delta Airlines discusses firm-specific risks and impacts of the disease. Of course, some of this variation may be driven by when exactly in the disease's course the calls occurred, which is why we control for the distance from January 1, 2020 in our econometric model. 


\section{Devon Energy (CEO Dave Hager speaking)}

Thanks, Scott and good morning everyone. For Devon, 2019 can best be defined as a year of exceptional execution and differentiating performance across every aspect of our business. As you can see on slide 5 of our operations report, a critical accomplishment during the year was our timely and tax-efficient transformation to a U.S. oil business. Even with the challenging market conditions, we successfully completed our portfolio simplification objectives in only 10 months and we're able to exit noncore assets at highly accretive valuations.

Furthermore, by sharpening our focus on Devon's world-class U.S. oil assets, we delivered a step change improvement in corporate level rates of return, achieved enhanced capital efficiencies, expanded our margins, reduced leverage and returned industry-leading amounts of capital to shareholders. All in all, it was a great year. But let me be clear, we are just getting started and the investment case for Devon has never been stronger.

Looking ahead to 2020, our strategic framework for success and disciplined capital priorities remain unchanged. These priorities are outlined on slide 10 of our operations report. As always, Devon's top priorities will be to fund the maintenance capital requirements of our business and the quarterly dividend. Once these objectives are met, next step in our capital allocation process is to selectively deploy capital to high-return projects that will efficiently expand the cash flow of our business.

Importantly, our 2020 plan meets all of these capital allocation priorities at low breakeven funding levels, even after accounting for the recent weaknesses in gas and NGL strip pricing. Should this volatility drive prices higher, we will remain disciplined and the benefits of any pricing windfall above our conservative base planning scenario will manifest itself in higher levels of free cash flow for shareholders, not higher capital spending. Conversely, should we see price volatility to the downside, we've designed our operating plan to have the flexibility and agility to reassess the capital program and react to any structural changes in the macro environment.

\section{Leggett \& Platt (CFO Jeffrey L. Tate speaking)}

Finally, we know impacts from the coronavirus, are top-of-mind for many of you, and we're closely monitoring global developments. Our current 2020 guidance does not include possible impacts from the virus. It's still too early to develop reasonable quantitative data related to the impact. Our first priority is the health and safety of our employees around the world. For our employees in China, we've extended the Lunar New Year plant shutdowns in accordance with Chinese provincial and local government extensions. We're establishing protocols in all 16 of our Chinese facilities to better protect our 5,200 employees in China when they can return to work...

And for all Leggett \& Platt employees around the world, we've implemented a travel ban to Asia, and are severely restricting all international travels. We're assessing the potential impact of this pandemic on our business, including demand for our goods and our customers' goods, inventory availability through our supply chain as well as our customers' supply chain, the global movement of goods and workforce availability. We do not anticipate that there are factors 
unique to us that will cause the impact from this coronavirus to be greater to our company than our global manufacturers - than other global manufacturers.

\section{Delta Airlines (CEO Ed Bastian speaking)}

None of us could possibly have anticipated the speed with which COVID-19 has affected the health of the world's people and slowed economies across the globe. This has led to an unprecedented situation where demand for near-term air travel dropped to almost zero in a matter of weeks.

Our response has been focused on three priorities. First, protecting the health and the safety of our employees and our customers. Second, preserving our financial liquidity to work through this crisis. And third, ensuring we're well positioned to recover once the virus is contained and building a plan to accelerate our progress through this period of recovery. Nothing is more important than the health and the safety of our people and our customers and we have substantially increased our investment in cleanliness across the organization. These include a wide range of safety and cleaning measures on our planes, at the airports and across our facilities and these actions won't end when the virus abates. We're taking steps to help our employees and customers practice social distancing. They include blocking middle seats, pausing automatic upgrades, modifying our boarding process and reducing meal service and other touch points.

On Monday, we received $\$ 2.7$ billion of the $\$ 5.4$ billion that's expected over the next few months. $\$ 3.8$ billion of this is direct aid with $\$ 1.6$ billion in a low interest unsecured 10-year loan. When you combine this release with our actions in the capital markets and our aggressive cost management, we expect to have at least $\$ 10$ billion in liquidity at the end of the June quarter. Since early March, we've raised $\$ 5.4$ billion in new financing and will likely raise several billion more this quarter, a strong indication of the confidence that the capital markets have in Delta. And while this will help ensure we have liquidity to weather the crisis with a more than $90 \%$ expected reduction in revenues this quarter. We needed to quickly address costs to stem cash burn. We have taken actions to reduce our total cost base by over $50 \%$ in the June quarter. This amounts to a $\$ 5$ billion reduction over the prior year which is impressive, given the very short frame with which we've had to get this done. And it was the great spirit of the Delta people that were a big part of making that happen. Right now 37,000 employees, more than onethird of our workforce have elected to take voluntary unpaid leaves ranging from 30 days to one year, a significant personal sacrifice that I will forever be grateful for. This is helping reduce our daily cash burn, which started at $\$ 100$ million per day in March, down to $\$ 50$ million a day, starting next month in May. Paul will go into more detail on these cost reductions and the cash burn trajectory that we are seeing.

After taking care of the safety of our customers and our people and protecting the financial liquidity of our enterprise, the third priority, we have is starting to build our recovery plan. These are truly unprecedented times and the path to recovery is uncertainty and will likely be choppy. And while we all wish we could predict the pace of the recovery, the truth is, our recovery will be dictated by our customers feeling safe, both physically and financially to begin to travel at scale. Given the combined effects of the pandemic and associated financial impact on the global economy, we believe that it could be up to three years before we see a sustainable recovery. And 
to succeed throughout that environment, we will likely need to resize our business in the near term to protect it in the long term. And while the resizing of our business over the short term is painful, it will also be an opportunity to accelerate strategies to streamline our Company, simplify our fleet and reduce our fixed cost base in ways not possible in the past.

It will allow us to advance the timelines of some of our critical airport infrastructure projects as we don't have the same constraints that limited progress and drove higher cost to construct it. We will be focused on what it takes to regain consumer confidence to travel and we are listing the very best medical advisors to help us navigate the journey from testing through to vaccines and helping translate those solutions to our business model. Safety will no longer be limited to flight safety, but personal safety as well. And while we may have more questions and answers about our path forward at present. One thing that is certain, it is that the strength that are core to Delta's business, our people, our brand, our network and our operational reliability are enduring. These advantages will continue to differentiate Delta and position us to succeed. 


\section{Supplementary Appendix 2}

Our main results show that partisan political positioning is correlated with perceptions of COVID-19 risk, as measured using transcripts from earnings calls occurring in the first quarter of calendar year 2020. We argue that the partisan positioning effect is largely due to the partisan valence associated with COVID-19 due to affective polarization and not underlying political associations with risk tolerance or perceptions. To bolster this claim, we conducted a supplementary analysis to examine whether partisan political positioning is associated with risk perceptions that carry no partisan valence. A null result would lend confidence to our interpretation that the partisan political valence surrounding COVID-19 affects how firms respond.

To test this argument, we conducted a supplementary analysis of risk perceptions from earnings calls occurring in the first quarter of calendar year 2019 (i.e., one year prior to COVID19 's emergence but in the same quarter). This dependent variable is the frequency of risk or uncertainty synonyms in the transcript, normalized by transcript length (number of words)..$^{13}$ The variable is $\log$ transformed to account for right-skewness. This measure does not give weight to any specific source of risk and thus should carry no salient partisan valence.

Our key independent variable is the political partisanship index, as described in the main text, occurring in the prior 10 years. We also control for other factors used in the main regression models, including donations to incumbents, logged lobbying expenditures, logged total assets, return-on-assets, debt-to-equity ratio, market-to-book ratio, institutional investor concentration, the partisanship imputation flag, and industry fixed-effects using 3-digit NAICS codes.

[ Insert Table SA2-1 about here ]

\footnotetext{
${ }^{13}$ Hassan et al make this variable available on their website, www.firmlevelrisk.com
} 
Table SA2-1 presents the OLS regression models, regressing perceived risk on the political partisanship index and covariates. All models show a null effect of political partisanship on disclosed risk; further, the estimated effect sizes are considerably smaller than the results in the main paper, and the estimates fail to reach statistical significance.

These results lend confidence to our argument that the political valence of COVID-19 due to affective polarization affects whether and how a firm's partisan political positioning matters. As an affectively politicized issue, firm's perceptions of COVID-19-related risk vary depending on their own partisan political positioning. However, partisan positioning matters does not have a significant impact on determining firms' responses to non-politicized issues. 
Table SA2-1: OLS regression models predicting disclosed risks in Q1 2019

\begin{tabular}{|c|c|c|c|}
\hline & $(1)$ & (2) & (3) \\
\hline Political Partisanship Index & $\begin{array}{c}-1.213 \\
(34.263)\end{array}$ & $\begin{array}{l}-21.433 \\
(39.063)\end{array}$ & $\begin{array}{l}-15.766 \\
(48.888)\end{array}$ \\
\hline Incumbent Contributions & & $\begin{array}{c}13.861 \\
(11.612)\end{array}$ & $\begin{array}{c}5.746 \\
(11.007)\end{array}$ \\
\hline CEO Partisanship Index & & $\begin{array}{c}17.573 \\
(10.796)\end{array}$ & $\begin{array}{c}14.275 \\
(15.493)\end{array}$ \\
\hline CFO Partisanship Index & & $\begin{array}{l}-11.763 \\
(14.622)\end{array}$ & $\begin{array}{l}-15.897 \\
(18.555)\end{array}$ \\
\hline Lobbying expenditures ${ }^{b}$ & & $\begin{array}{c}.367 \\
(.297)\end{array}$ & $\begin{array}{c}1.150^{* * *} \\
(.401)\end{array}$ \\
\hline Total assets ${ }^{b}$ & & $\begin{array}{c}6.231^{*} \\
(3.069)\end{array}$ & $\begin{array}{l}11.890^{*} \\
(4.628)\end{array}$ \\
\hline Return on assets & & $\begin{array}{l}-15.447 \\
(26.846)\end{array}$ & $\begin{array}{c}-2.339 \\
(40.202)\end{array}$ \\
\hline Cash on hand & & $\begin{array}{l}-16.795 \\
(22.772)\end{array}$ & $\begin{array}{l}-51.375 \\
(35.135)\end{array}$ \\
\hline Leverage & & $\begin{array}{c}-20.463 \\
(12.767)\end{array}$ & $\begin{array}{c}-26.469 \\
(16.371)\end{array}$ \\
\hline Market to Book & & $\begin{array}{l}-.001 \\
(.019)\end{array}$ & $\begin{array}{l}-.039 \\
(.073)\end{array}$ \\
\hline Institutional investors (HHI) & & $\begin{array}{c}6.697 \\
(16.680)\end{array}$ & $\begin{array}{c}7.577 \\
(20.143)\end{array}$ \\
\hline HQ state Democratic governor & & $\begin{array}{l}-2.312 \\
(5.609)\end{array}$ & $\begin{array}{l}-3.170 \\
(7.638)\end{array}$ \\
\hline HQ state policy index & & $\begin{array}{c}1.559 \\
(2.218)\end{array}$ & $\begin{array}{c}2.953 \\
(3.117)\end{array}$ \\
\hline ESG Rating & & $\begin{array}{l}-.045 \\
(.352)\end{array}$ & $\begin{array}{l}-.184 \\
(.426)\end{array}$ \\
\hline China-exposure & & $\begin{array}{c}.069 \\
(.202)\end{array}$ & $\begin{array}{l}.113 \\
(.288)\end{array}$ \\
\hline Other Asia-exposure & & $\begin{array}{l}-.032 \\
(.119)\end{array}$ & $\begin{array}{l}-.020 \\
(.175)\end{array}$ \\
\hline Europe-exposure & & $\begin{array}{l}-.056 \\
(.080)\end{array}$ & $\begin{array}{l}-.095 \\
(.102)\end{array}$ \\
\hline Percentage foreign revenue & & $\begin{array}{c}4.346 \\
(11.215)\end{array}$ & $\begin{array}{c}7.521 \\
(16.869)\end{array}$ \\
\hline Call date (days since Jan 1,2020 ) & $\begin{array}{l}.064 \\
(.212)\end{array}$ & $\begin{array}{l}.257 \\
(.239)\end{array}$ & $\begin{array}{l}.817 \\
(.417)\end{array}$ \\
\hline Partisanship index imputed flag & $\begin{array}{l}-6.716 \\
(5.618)\end{array}$ & $\begin{array}{c}13.207 \\
(11.660)\end{array}$ & . \\
\hline Constant & $\begin{array}{l}65.283^{\text {**** }} \\
(16.345)\end{array}$ & $\begin{array}{c}6.212 \\
(32.177)\end{array}$ & $\begin{array}{l}-87.379 \\
(50.994)\end{array}$ \\
\hline $\begin{array}{l}\text { Industry FEs } \\
N\end{array}$ & $\begin{array}{l}\text { Yes } \\
509\end{array}$ & $\begin{array}{l}\text { Yes } \\
509\end{array}$ & $\begin{array}{l}\text { Yes } \\
340\end{array}$ \\
\hline
\end{tabular}

${ }^{\mathrm{a}}$ Robust Standard errors in parentheses

${ }^{\mathrm{b}}$ Variable is log-transformed 